\title{
腎結核に対する化学療法の影響, 特に腎機能について
}

\section{附） 肝機能及び血圧との関係}

\author{
弘前大学医学部皮膚科泌尿器科教空 \\ （主任：帷子康雄教授）菅营 \\ (院長: 渡辺栄市博士)
}

\section{THE INFLUENCE OF CHEMOTHERAPY ON RENAL TUBERCULOSIS THE INFLUENCE ON RENAL FUNCTION AND THE RELATION BETWEEN RENAL FUNCTION AND LIVER FUNCTION AND BLOOD PRESSURE}

Toru Sugawara

Dermato-Urological Department of Hirosaki University, Hirosaki

(Director: Prof. Y. Katabira)

Dermato-Urological Department of Watanabe Hospital, Hakodate

(Dr. E. Watanabe)

The author classified 157 cases of renal tuberculosis, whose renal functions could be examined before and after chemotherapy, into group I, 106 cases of nephrectomy and chemotherapy, group. II, 51 cases of chemotherapy only, and group III, 20 cases of nephrectomy only. These 51 cases belonged to group II were further classified into:-(a) 14 cases of unilateral renal tuberculosis, (b) 20 cases of bilateral one, and (c) 17 cases of tuberculosis of the remaining kidney after nephretomy. As the control group, 34 cases of non-tuberculous renal diseases and 15 cases of nephritis were collected. These cases of chomotherapy, chiefly by SM, were also devided into four groups according to dosage: less than $15 \mathrm{~g}, 16-30 \mathrm{~g}, 31-60 \mathrm{~g}$ and more than $60 \mathrm{~g}$. The examination of renal functions was done through the test of indigocarmin excretion, the concentration and dilution test, PSP test, NPN and urea clearance.

The results obtained were as follows:

1) The improvement of renal functions in the nephrectomy group (including the cases with combined use of chemotherapy) was more favourable than in the chemotherapy group except in the NPN.

2) The relations between the improvement of renal functions and the dosage of SM (as stated above) were as follows:

a) Indigocarmin excretion test showed that the dosage of $30 \mathrm{~g} \mathrm{SM}$ gave the highest proportion of improvement in groups I and II (a) and (b) and that a higher dosage seemed to have nothing to do with the improvement of the renal function. However, in the cases of tuberculosis of the remaining kidney, a dosage of $60 \mathrm{~g}$ showed a higher percentage of improvement.

b) The same tendency as showed in (a) was observed in the concentration and dilution test, PSP test, NPN and urea clearance. Generally, these tests showed that a greater dosage of SM seemed to be required for the improvement of renal functions than that showed in the concentration and dilution test.

3) The correlation between urea clearance and other tests before and after the use of SM: There was significant correlation between the concentration and dilution test and urea clearance except in group I, but even in the cases of group I there was significant correlation after medical treatment, In groups I and II (a), there was not so close a correlaton with PSP test before 
and after treatment. Significant inverse correlation with NPN before and after treatment was shown in group II, and the same is the case with group I and II after treatment,

4) The functions of liver and kidney were so closely connected that they often run parallel to each other.

In cases of impediment to both liver and renal functions, it was revealed that the improvement of liver functions might take place later than that of renal functions.

5) The relation with biood pressure: In the cases of nephrectomy (including the case with combined chemotherapy), the cases of falling blood pressure just after treatment were more frequently encountered than in the cases of chemotherapy only. In each group, as time went on after the treatment, the cases of rising blood pressure gradually increased in number, and those of falling blood pressure decreased.

6) Through this observation of renal function, it was reaffirmed that all the cases of renal tuberculosis could not be cured by chemotherapy alone, at least for the time being.

\section{緒呾}

腎結核に於ける腎機能に関しては，本邦に於いても既 に多数の報告 ${ }^{1)}$ 10) $^{13}$ 輩出しているが, 腎機能改善とス トレプトマイシン (SM と略) 投与量との関係等につい ての検討は余り行なわれて扔らない。腎結核に対する $\mathrm{S}$ M療法は必ずしも満足すべきものでなく，耐性菌の出現 等種々の問題もあり, カナマイシン其他による治療が漸 く一般化せんとしている現在，SM療法の腎機能に及卧 す影響等は再検討を加えて然るべき問題と考えられる. 先に教室の荒川・近藤 ${ }^{11)}$ 13) 注化学療法の腎結核に及ぼ す影響について諸種の観察を行ない腎機能にも一部触れ たが著者は今回, 各種腎機能につき化学療法施行前後に 於ける成績の比較を行ない, その遠隔成績を追及すると 共汅, てれら機能の相互関係及び 2,3 臨床検查成績と の関係を吟味したのでことに報告する.

\section{観察対象}

昭和 25 年 1 月～同 34 年 10 月 に於ける入院腎結核患者 で，化学療法施行前後に腎機能検查を行ない得た 157 例 を次の如く分類して調查した. 即与, 第 I 群化学潦法兼 腎摘出施行 106例, 第 II 群化学療法単独施行51例及び第

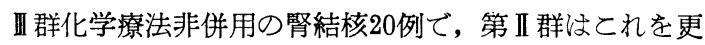
に a 偏側性 14 例, b 両側性 20 例, c 残腎結核17例とに分 け，対照群としては非結核性腎・尿管疾患34例及び腎炎 15例を以ててれに当てた.なお,化学療法剤は主としてS

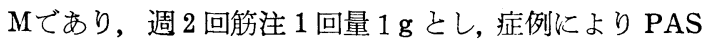
(1 日量10g) ・ INAH・TBI (同 100 200mg) ・ IHMS (同 $500 \mathrm{mg}$ ) 内服等を適宜併用したが, SM単独使用例と 比較して腎機能に対する効果の点に於いて格別な差異㳉 認められなかつたので，本稿では SM 療法を主体とし て且つ投与量を $15 \mathrm{~g}$ 以下， $16 \sim 30 \mathrm{~g}, \quad 31 \sim 60 \mathrm{~g}$ 及び $61 \mathrm{~g}$ 以上の 4 段階に分けて検討を試みた。

\section{検索事項並びに方法}

1) インヂゴカルミン(IC と略)排泄試験：0.25\% IC 液 $5.0 \mathrm{cc}$ の静脈内注射を行ない, 5 分以内核登の見元 ないもの, 及び初発が 5 分以内であつても 7 分以内に濃 青とならないものを IC 排泄機能障害とし, 然らざるお のは正常範囲と判定した. 治療後に初発時間が 1 分以上 短縮したものを好転と見做し, 逆に 1 分以上延長乃至排 泄の全く認められなくなつたものを惡化とした。

2）水試験：Volhard ${ }^{16)}$ の方法に従い，水 $1 l$ を摂 取せしめ稀釈試験と濃縮試験を同日連続して行なつた. 判定は機能指数 $\mathrm{F}=$ ( 4 時間内排泄量/ $100+24$ 時時内 比重差) を以てした. 即ち, 機能指数19以下を障害 と 乙, 治療後機能指数 5.0 以上増加を好転, 5.0 以上減少 を惡化とした. なお治療前機能指数が既に20以上の場合 でも5 以上増加は好転例に含めた。

3）PSP 排泄試験：排尿後, 型の如く, 水 $300 \sim 400$ ccを飲用させ， 30 分後に $0.6 \%$ ェノールズルフホフ タレン溶液 $1.0 \mathrm{cc}$ を正確に静注後, 15 分, 30 分, 60 分, 120分に分割採尿し各々につき Dubosco 比色計で比色 測定した. 富川 ${ }^{4)}$, 根岸 ${ }^{3}$ 等は PSP 1 時間值が妥当で, 2 時間値は腎盂に㵔溜した尿の逆吸収による影響を受け ると報告しているが, 著者の場合は，120分までの測定 值の和が $60 \%$ 以下又は 15 分，30分，60分値の和が $45 \%$ 以 下が機能障害と判定されており，2 時間值を比較 治療 後10\%以上增加を好転, $10 \%$ 以上減少を惡化とした。

4）血中残余窒素值(NPN と略)：Kjeldahl Nabler's $\operatorname{method~}^{16)}$ により測定し, $40 \mathrm{mg} / \mathrm{d1}$ 以上を腎機能障害と判 定し, 治療後 $6 \mathrm{mg} / \mathrm{d} 1$ 以上減少を好転, $6 \mathrm{mg} / \mathrm{dl} \sim 10 \mathrm{mg} / \mathrm{dl} の$ 增加をや>惡化, $11 \mathrm{mg} / \mathrm{dl}$ 以上増加を惡化とした. 但し障 害の認められないものが, 治療後增加しても $40 \mathrm{mg} / \mathrm{dl}$ 亿達 しない場合は不変と看做した。 
5）稳睡尿案クリアランス（尿素クと略）：尿素測定 は Diacetyl monoxime 法 ${ }^{17)}$ により測定し, 次の関係 式よりクリアランス值を求めた。 即与, 尿量が 1 分間 2 cc以上の場合 $\mathrm{Cm}=\frac{\mathrm{UV}}{\mathrm{B}} \times \frac{1.48}{\mathrm{~A}} \times \frac{100}{70}, 2 \mathrm{cc}$ 以下 の場合 $\mathrm{Cs}=\frac{\mathrm{U} \sqrt{\mathrm{V}}}{\mathrm{B}} \times \frac{1.48}{\mathrm{~A}} \times \frac{100}{50}$

但し $\mathrm{U}=$ 尿中尿素濃度 $(\mathrm{mg} / \mathrm{dl}) \mathrm{V}=1$ 分間尿量 $(\mathrm{cc})$,

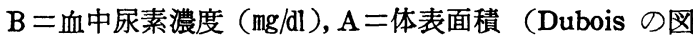
表 $\left.{ }^{16)}\right)$ によ，身長, 体重から算出, 又1.48は大島 ${ }^{18}$ に よる日本人体表面積数值 $(\mathrm{m} \times \mathrm{m})$ である．尿素クの正 常値としては 70〜 130\% (金子・大島 ${ }^{18)}$ ), 65〜 130\% (富川4) 等が挙げられて扔るが，70\%未満を腎機能減 退，50\%未満を機能障害と判定した。 又治療後 $10 \%$ 以上 の増加を好転，10\%以上の減少を惡化とした．なお，前 值70\%以上の場合は治療後の増加は不変と看做した。

6）尿一般所見：治療前後に於ける 尿の溷濁，赤血 球，白血球，蛋白及び結核菌の消長を比較し， 2 種類以 上の検査項目が著明に減少ないし消失せる場合を好転と した，なお，尿蛋白は末吉氏定量法により $1.0 \%$ 以上を (H), $0.5 \sim 0.9 \%$ を(H), $0.2 \sim 0.4 \%$ を (十), 0.1 \%前後を（士), $20 \%$ スルフホサリチル酸による定性法て も尿蛋白の証明されないものを（一）とした．又結核菌 は治療前遠沈塗抹又は培養にて確認されるものを陽性と し, 治療終了後培養にて 3 回以上陰性のものを菌消失と 判定した.

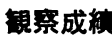

\section{I ）一般的事頂}

表 1 観察対象内訳

\begin{tabular}{|c|c|c|c|c|c|c|c|c|c|c|c|c|c|}
\hline & \multicolumn{2}{|c|}{ 性 } & \multicolumn{2}{|c|}{ 年 } & \multicolumn{3}{|c|}{ 令 } & \multicolumn{2}{|l|}{ 患 } & 側 & \multirow{2}{*}{ 備 } \\
\hline & & & $\hat{o}$ & 우 & $\begin{array}{l}11 \sim \\
20 f\end{array}$ & $\begin{array}{l}21 \sim \\
30 \mathrm{f}\end{array}$ & $\begin{array}{l}31 \sim \\
40 f\end{array}$ & $\begin{array}{l}41 \sim \\
50 \text { 才 }\end{array}$ & $\begin{array}{l}50 \text { お } \\
\text { 以上 }\end{array}$ & 右 & 左 & 両 & \\
\hline \multirow[t]{2}{*}{ 腎 } & \multicolumn{2}{|c|}{ 第 I 群 } & 54 & 52 & 21 & 42 & 32 & 8 & 3 & $\begin{array}{l}40 \\
(5)\end{array}$ & $\begin{array}{l}60 \\
(7)\end{array}$ & 6 & \multirow[t]{2}{*}{$\begin{array}{l}\text { 华学㙩法, 腎摘出術併 } \\
\text { 型 }\end{array}$} \\
\hline & & $\begin{array}{c}a \\
\text { (偏側性) } \\
\end{array}$ & 11 & 3 & 3 & 6 & 3 & 1 & 1 & 7 & 7 & & \\
\hline \multirow[t]{2}{*}{ 結 } & & $\begin{array}{c}\mathrm{b} \\
\text { (両側性) }\end{array}$ & 13 & 7 & 1 & 4 & 7 & 6 & 2 & & & 20 & \multirow[t]{2}{*}{ |化学療法単独 } \\
\hline & 群 & (残 & 9 & 8 & 2 & 3 & 6 & 4 & 2 & 7 & 10 & & \\
\hline 核 & & III 群 & 10 & 10 & 3 & 10 & 6 & 1 & 0 & $\begin{array}{l}7 \\
(4)\end{array}$ & $\begin{array}{c}9 \\
(6)\end{array}$ & 4 & $\begin{array}{l}\text { 花学療法非施行, 腎摘 } \\
\text { 出 }\end{array}$ \\
\hline \multicolumn{3}{|r|}{ 計 } & 97 & 80 & 30 & 65 & 54 & 20 & 8 & 61 & 86 & 30 & \\
\hline \multirow{2}{*}{$\begin{array}{l}\text { 対 } \\
\text { 照品 }\end{array}$} & & a & 24 & 10 & 0 & 12 & 12 & 2 & 8 & 19 & 11 & 4 & 非結核性腎尿管疾患 \\
\hline & & b & 7 & 8 & 4 & 6 & 2 & 2 & 1 & & & & 腎炎 \\
\hline
\end{tabular}

註（）は患腎摘出後残堅結核となつた例数 i ） 性別・年令及び患側等に関しては表 1 に示す通 りであり，I～四群に於ける成績は荒川, 近藤 ${ }^{11)}$ の統計 的観察と大差がない．な㧍，I群即ち化学療法を併用せ る腎摘出術施行例で，術後残腎結核になつたものが12例 $12 \%$ に対し化学療法の併用の行なわれない四群のそれは 10例 $62.5 \%$ と高率を示している.

ii ）病期及び発病より来院迄の期間は，I 群 106例 の摘出腎では初期 7 例 $6.6 \%$, 完成期 84 例 $79.2 \%$ (閉塞 性 4 例，遮断性 3 例)，末期 15 例 $14.2 \%$ で，来院迄の日数 は最短 2 週間, 最長 4 年, 平均 9.1 力月となる. 又再発 は 12 例で最短 1 年, 最長 6 年, 平均 4 年後である. II 群 のレ線像よりみた病期は $\mathrm{a}$ の偏側性14例では初期 6 例, 完成期 8 例, 来院迄の日数は最短 10 日, 最長 1 年で, 平 均 5.5 力月, 再発は初期 5 例で最短 4 力月, 最長 2 年平 均 8.5 力月後となる. な掞, 完成期 8 例の中 6 例恃本調 查後腎摘出術が施行された。 b の両側性20例では完成期 9 例 $45 \%$ (閉塞性 1 例, 遮断性 1 例),末期 11 例 $55 \%$ （閉 塞性 3 例) で，亏5完成期の 1 例は 8 力月後末期像を呈 した. 来院迄の日数恃最短 1 力月, 最長 10 年, 平均 2.9 年である. $\mathrm{c}$ 即ち残腎結核17例では初期16例，完成期 1 例で 摘出時期は 発病後平均 6.3 年で, 再発後来院迄は 1.4 カ月となつている．群では腎摘出術のみ施行の 20 例は初期 3 例, 完成期13例, 末期 4 例て，来院迄の期間は 最短 2 週間, 最長 2 年, 平均 9.2 力月である. 再発の証 明されたものは 10 例で, 期間は最短 3 力月, 最長 4 年, 平均 1.3 年である. 次に非結核性腎尿管疾患 34 例の内訳 
表 2 インヂゴカルミン排泄試験と S M 量

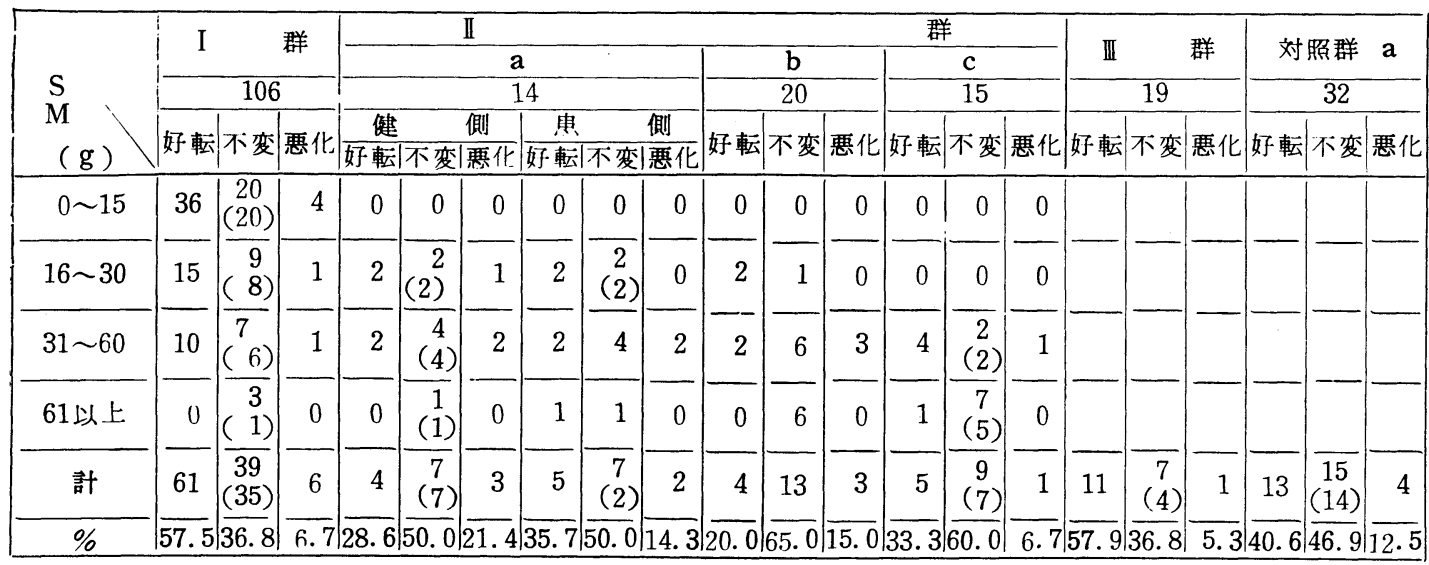

註（）不变良好例数

将腎・尿管22例遊走腎 5 例, 腎腫湟・腎水腫各 2 例, 矮 小腎・腎脿腫・腎周囲炎各 1 例で, 来院迄の期間は最短 2 週間, 最高 7 年, 平均 1.3 年である. 又腎炎の 15 例は 急性 11 例, 慢性 2 例, 腎孟腎炎 2 例で, 来院迄㵊短 1 週間, 最長 1 年, 平均 2.3 力月を要している. 発病より 来院迄の期間の短いのはII群の $\mathrm{c}$, 次いで $\mathrm{a}$ であるが, てれは一度腎摘出を受けており，結核に対して細心の注 意を払つている故当然であり, a は初期のものが比較的 多い為結果に於いて, かくなつたものと考えられる. 又 再発は非手術群の $\mathrm{a}$ に多く, かつ期間も早い点, 化学療 法だけでは根治が不可能なととを立証するものであろ 3.

\section{II）艿機能}

i ） IC 排泄試験（表 2） 1 群：106例（治療前 健側の良好89例, 患側の稍 $<$ 良好17例) のう5, 治療終 了後好転 61 例 $57.5 \%$, 不変 39 例 $36.8 \%$ (良好不変 35 例, 不良不変 4 例), 惡化 6 例 $5.7 \%$ あるる. 好転の61例 SM 使用量内訳は10 15g が36例59.0\%，16〜30g 15例24.6 $\%, 31 \sim 60 \mathrm{~g} 10$ 例16.4\%である. 治療後機能正常16例の $1 \sim 6$ 年後に於ける遠隔成績では 12 例 $75.0 \%$ が良好な機 能を持続していた.

II 群 : a 偏側性腎結核14例では治療前健側の稍こ不良 1 例 $7.2 \%$, 患側の不良 5 例 $35.7 \%$, 治療終了後健側の好 転は 4 例 $28.6 \%$, 不変 7 例 $50.0 \%$ (何れも良好不変), 惡 化 3 例 $21.4 \%$. 好転の 4 例の $\mathrm{SM}$ 使用量内訳は $30 \mathrm{~g}$ 以 内, $31 \sim 40 \mathrm{~g}$ 各 2 例である. 又患側の好転は 5 例 $35.7 \%$, 不変 7 例 $50.0 \%$ (良好 2 例, 不良 5 例), 惡化 2 例 $14.3 \%$ となつて拈り，好転 5 例の $\mathrm{SM}$ 使用量は $16 \sim 30 \mathrm{~g}, 31$ $\sim 40 \mathrm{~g}$ 各 2 例, $41 \sim 60 \mathrm{~g} 1$ 例である. $\mathrm{b}$ 両側性腎結核 20 例では治療前稍 例 $20.0 \%$, 不変 13 例 $65.0 \%$ (何孔も不变不良), 惡化 3 例 $15.0 \%$ あるる. 好転 4 例のSM使用量は $16 \sim 30 \mathrm{~g} 2$ 例, $31 \sim 40 \mathrm{~g}, 41 \sim 50 \mathrm{~g}$ 各 1 例である. $\mathrm{c}$ 残腎結核15例では 治療前良好 8 例, 不良 7 例, 治療後好転は 5 例 $33.3 \%$, 不変 9 例 $60.0 \%$ （不良不変 2 例）惡化 1 例 $6.7 \%$ て る. 好転 5 例の $\mathrm{SM}$ 使用量は $31 \sim 60 \mathrm{~g} 4$ 例, $61 \mathrm{~g}$ 以上 1 例である.なお, 不变例のうち遠隔成績の判明せる 8 例 では好転例がなく 6 例は更に惡化し，亏55例は死亡し ている.

I群：19例では術前稍 $く$ 良好 4 例, 不良 15 例, 術後 1 ～1.5力月に於ける 成績は好転11例57.9\%, 不变 7 例 $36.8 \%$ (良好 4 例, 不良 3 例), 惡化 1 例 $5.3 \%$ となつて いる. 遠隔成績では $6 \sim 10$ 年後の不变及び惡化の 8 例中 良好 3 例, 不变 2 例, 惡化 3 例である.

対照群 : a 非結核性腎・尿管疾患32例では術前患側不 良11例で術後10日〜 1 力月で健側の好転13例 $40.6 \%$, 不 変 15 例 $46.9 \%$ (良好 14 例, 稍 $<$ 不良 1 例), 惡化 4 例 12.5 \%となつている. 遠隔成績では不変のもの 5 例中 3 力月 $\sim 1$ 年後良好 2 例, 不変 2 例死亡 1 例である. b 腎炎 の 3 例は治療前後の成績は何れも不変で 7 分以内に初発 をみている.

ii）水試験（表 3，7）I群：35例中，治療前機能 指数 20 以上注 23 例 $65.7 \%$ て これらの機能正常例を含め 乙治療後 17 例 $48.6 \%$ ，不変 15 例 $42.9 \%$ （何れも良好不 変), 惡化 3 例 $8.5 \%$ (治療前良好 2 例，不良 1 例) とな つている. 好転17例のSM 使用量内訳は $15 \mathrm{~g} 3$ 例, 16 
表 3 水試験（機能指数）と S M 量

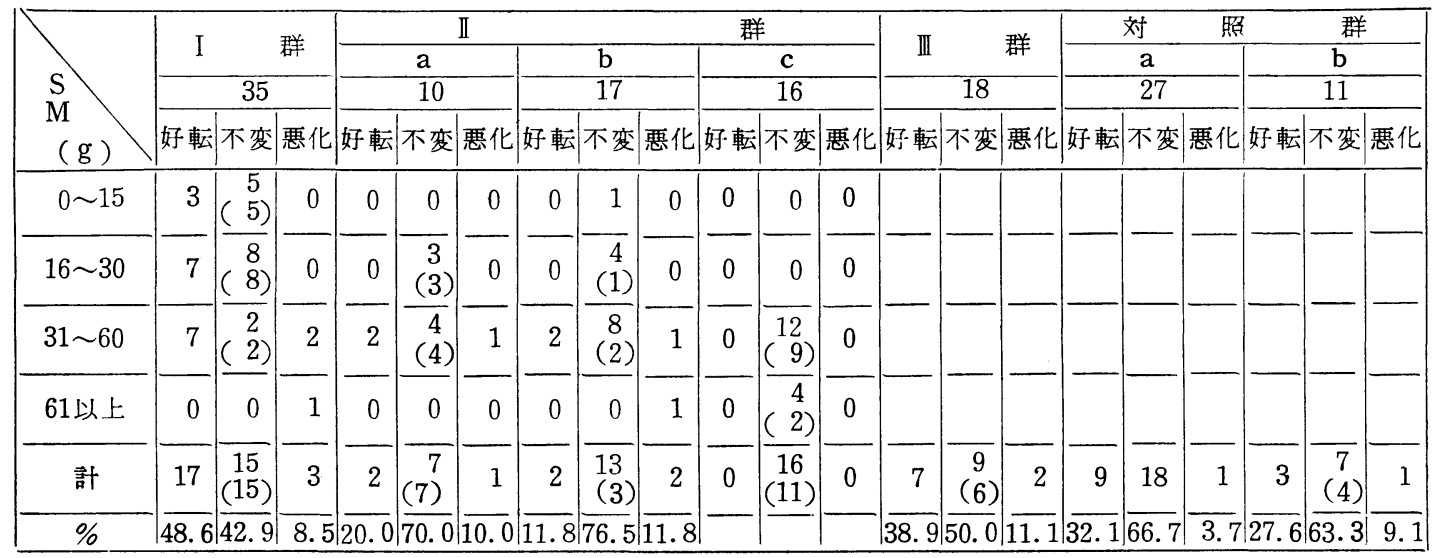

註（）不变良好例数

$30 \mathrm{~g}, 31 \sim 60 \mathrm{~g}$ 各 7 例である. 治療終了直後機能指数 20 以上を示した 5 例の遠隔成績をみると 3 年後も不変で 20 以上のもの 3 例, 惡化 2 例, 同じく機能指数 $15 \sim 19 の$ 3 例では 2 年後不変 1 例, 3 年後の検査では好転, 不変 各 1 例であつた. SM 使用前後の機能指数を比較すると SM30 40g の27例では使用前 $23.9 \pm 6.1$, 使用後 27.7 \pm 5.0 で13.5\%の堌加率を示し，1\%の危険率で有意の 差が認められる. 次に SM $41 \mathrm{~g}$ 以上の 8 例では使用前 $19.6 \pm 4.1$, 使用後 $21.9 \pm 6.9$ で増加率は $10.5 \%$ である が両者の間に有意差はない。

II 群 : a 10例の治療前機能指数は全例20以上で，化学 療法終了後好転 2 例 $20.0 \%$, 不変 7 例 $70.0 \%$, 惡化 1 例 $10.0 \%$ であ. 好転 2 例は共に SM 31 60g 使用例であ つた. SM 使用前機能指数平均値は $27.0 \pm 3.9$, 使用後 $26.9 \pm 5.6 て ゙ ， 0.4 \% の$ 減少を示しているが有意差でな い. b 17 例中治療前機能指数 20 以上は 4 例 $23.5 \%$ で化 学療法後好転 2 例 $11.8 \%$, 不変 13 例 $76.4 \%$ (良好 3 例, 不良10例), 惡化 2 例 $11.8 \%$ である. 好転 2 例は共に $\mathrm{SM}$ $31 \sim 60 \mathrm{~g}$ 使用例である. 遠隔成績の判明せる不変 6 例 では, 2 年後惡化 1 例, 3 年後不变惡化各 2 例, 8 年後 不変 1 例となつている. SM 使用前機能指数は平均 16.6 \pm 6.3 , 使用後 $17.0 \pm 6.7 て ゙ ， 2.5 \%$ 増加率を示すが 有意差ではない. c 16例の中, 治療前機能指数 20 以上 は 11 例 $68.8 \%$ で, 化学療法終了後は何れも不変であつ た. SM 使用量は $31 \sim 60 \mathrm{~g}$ 12例, $61 \mathrm{~g}$ 以上 4 例である. SM 使用前の機能指数注, 使用前 21.9 , 使用後 $22.8 \pm$ 3.9で 3.8\%の増加率を示したが有意の差はない。

III群：18例中治療前機能指数 20 以上注 8 例 $44.4 \%$ で,
腎摘出後好転 7 例 $38.9 \%$, 不変 9 例 $50.0 \%$ (良好 6 例, 不良 3 例), 惡化 2 例 $11.1 \%$ でる. 遠隔成績の判明せる 4 例の中 2 例は 10 年後も不変良好であり, 2 例は 5 年, 11 年後夫々惡化している. 腎摘出前機能指数恃平均 21.5 \pm 5.1 , 術後 $23.4 \pm 5.8$ で增加率は $8.3 \%$, 両者の間 に $5 \%$ の危険率で有意差が認められる.

対照群：a の27例中治療前の機能指数 20 以上 15 例 55.6 $\%$, 術後好転せるもの 9 例 $33.3 \%$, 不変 18 例66.7\%（良 好 15 例, 不良 3 例), 惡化なしで, 遠隔成績の判明せる 5 例（ 3 カ月〜 1 年）は何れも不変不良の機能を維持して いた. 手術前機能指数は平均 $24.1 \pm 6.4$ 術後 $29.0 \pm 5.5$ で増加率は $15.2 \%$ 示し， $1 \%$ の危険率で有意の差が認 められた，b の腎炎 11 例中, 治療前機能指数 20 以上は 4 例 $20.0 \%$, 治尞後好転 3 例 $27.6 \%$, 不変 7 例 $63.3 \%$ (正 好 4 例, 不良 3 例）惡化 1 例 $9.1 \%$ ある. 治療前の指 数は平均19.7 4.9 , 治療後 $21.5 \pm 4.2$ で增加率は 8.3 \%であるが有意の差ではない。

iii）PSP 試験（表 4，8） I 群：45例中治療前 2 時間 $70.0 \%$ 以上 15 例 $33.3 \%$, 治療後好転 19 例 $42.2 \%$, 不変 25 例 $55.5 \%$ (良好 15 例, 不良 10 例), 惡化 1 例 $2.3 \%$ で, 好転19例の SM 使用量は15g 4 例, 16 30g 8 例, $31 \sim 60 \mathrm{~g} 6$ 例となり， $61 \mathrm{~g}$ 以上は 1 例である. 遠隔成 績の判明せるものでは 3 年後惡化 1 例, 不変 2 例, 4 年 後惡化, 不変各 2 例となつている. SM 使用前後の成績 を比較すると SM $40 \mathrm{~g}$ 以内投与 38 例では使用前59.2士 $5.7 \%$, 使用後61.7士 5.9\%で 4.1\%の増加率, S M41 $\mathrm{g}$ 以上投与 7 例の 使用前平均値 $66.0 \pm 15.8 \%$, 使用後 $74.1 \pm 13.2 \%$ で，10.9\%の増加率を示したが夫々有意の 
表 4 P S P 試験と S M 量

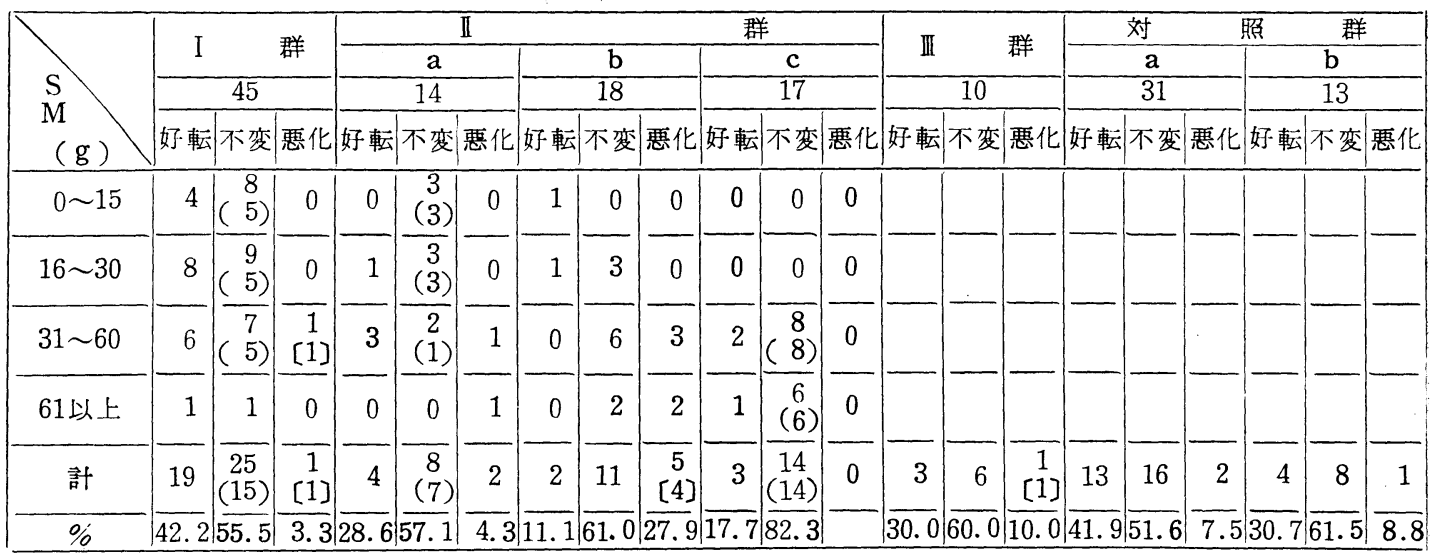

註（）不変良好例〔 〔 ]死亡例

差とは云い難い.

II 群：a の14例では治療前 2 時間値 $70.0 \%$ 以上 6 例 $42.8 \%$, 治療後好転 4 例 $28.6 \%$, 不変 8 例 $57.1 \%$ (良好 7 例, 不良 1 例), 惡化 2 例 $14.3 \%$ ある. 好転 4 例の $\mathrm{SM}$ 使用量は $30 \mathrm{~g}$ 以内 1 例, $31 \sim 60 \mathrm{~g} 3$ 例である. 遠隔 成績の判明せるもの 1 例のみで 5 年後に惡化している.

SM 使用前平均值は $66.1 \pm 9.1 \%$ ，使用後 $70.3 \pm 11.8$ \%で6\%の増加率であるが，有意の差ではない， b 18 例では治療前70.0\%以上の例はなく, 治療後も70.0\%に 達したものはないが, 治療後好転 2 例 $11.1 \%$, 不変 11 例 $61.1 \%$ ，惡化 5 例 $27.8 \%$ である. 好転例の SM 使用量 は $15 \mathrm{~g}, 16 \sim 30 \mathrm{~g}$ 各 1 例で, 不変はすべて $31 \mathrm{~g}$ 以上であ る. SM 使用前平均值は $35.1 \pm 17.7 \%$, 使用後 $35.5 \pm$ $21.7 \%$ と殆えど変化を認妨孔ない. c 17例中治療前 $70.0 \%$ 以上以 2 例 $11.8 \%$ で, 治療後好転 3 例 $17.7 \%$, 不 変14例 $82.3 \%$ で惡化はなく, SM 使用量は好転例中 2 例 は $60 \mathrm{~g}$ 以内, 1 例は $61 \mathrm{~g}$ 以上, 不変はすべて $61 \mathrm{~g}$ 以上 である. SM 使用前の平均値 $58.7 \pm 11.6 \%$ 使用後 (40 $80 \mathrm{~g}) 60.7 \pm 9.2 \%$ で両者の間仿有意の差はない.

III群：10例中治療前70.0\%以上は 1 例10\%のみで，督 摘出後好転 3 例 $30.0 \%$, 不変 6 例 $60.0 \%$ (良好 1 例, 不 良 5 例), 惡化 1 例 $10.0 \%$ ある. 遠隔成績では 1 例が 5 年後機能惡化 (死亡) 他の 1 例は 11 年後に惡化を及てい る.な㧍, 術前平均值註 $62.0 \pm 9.5 \%$, 術後 $63.2 \pm 10.1$ \%で両者の間に有意の差はない。

対照群：a 31 例中， 2 時間値70.0\%以上 13 例 $41.9 \%$, 術後好転 13 例 $41.9 \%$, 不変 16 例 $51.6 \%$ (良好10例, 不良 6 例), 惡化 2 例 $(6.5 \%)$ である. 術前平均值は59.1土
$18.6 \%$, 術後66.0土15.4で10.6\%增加率を示し, 危険率 $1 \%$ で有意の差が認められる.b 13例中 2 時間值 $70.0 \%$ 以上は 1 例 $7.8 \%$ 凤て，治療啳好転 4 例 $30.7 \%$, 不 变 8 例 $61.5 \%$ (良好 1 例, 不良 7 例)，悪化 $7.8 \%$ あ る. 治療前平均值は51.6土11.4\%, 後55.0 $010.7 て ゙ 6.2$ \%の増加率があるが有意の差ではない。

iv）血中残余窒䒺（表 5，9）I群：26例中治療前 值が $35.0 \mathrm{mg} / \mathrm{d} 1$ 以下は 17 例 $65.4 \%$ で, 腎摘出・化学療法併 用後好転 10 例 $38.5 \%$ ，不変 12 例 $46.2 \%$ (何れも良好不 変), 惡化 4 例 $15.3 \%$ (良好 2 例, 不良 2 例) である. 好 転10例の SM 使用量は $30 \mathrm{~g}$ 以内 4 例, $31 \sim 60 \mathrm{~g} 4$ 例, $61 \mathrm{~g}$ 以上 2 例である. 良好不変 3 例の 3 年後に於ける遠 隔成績は何れも不変であつた. 治療前の平均值络 SM40 $\mathrm{g}$ 以内のもの 20 例では $33.2 \pm 7.9 \mathrm{mg} / \mathrm{dl}$, 使用後 $30.9 \pm$ $6.6 \mathrm{mg} / \mathrm{dl}$ と $6.9 \%$ の減少率を示したが，有意の差ではな い. 又 S M $41 \mathrm{~g}$ 以上投与の 6 例では治潦前 $44.3 \pm 12.9$ $\mathrm{mg} / \mathrm{dl}$, 後31.2 $\pm 11.7 \mathrm{mg} / \mathrm{dl}, 29.6 \%$ 減少率を示したが, 有意の差ではない.

II 群 : a 10 例中治療前 $35.0 \mathrm{mg} / \mathrm{dl}$ 以下 7 例 $70.0 \%$ で治療 後好転せるものは 3 例 $30.0 \%$, 不变 7 例 $70.0 \%$ (何れも 良好不変), 惡化なし, 好転 3 例の SM 使用量注 $15 \mathrm{~g}, 16$ $\sim 30 \mathrm{~g}, 31 \sim 60 \mathrm{~g}$ 各々 1 例である. 化学療法前平均值! $32.9 \pm 4.8 \mathrm{mg} / \mathrm{dl}$, 後 $29.1 \pm 4.2 \mathrm{mg} / \mathrm{dl}$ そ11.8\%の增加率芒 示すが有意の差と法云い難い. b 19 例中治療前値 35.0 $\mathrm{mg} / \mathrm{dl}$ 以下 9 例 $47.4 \%$, 治爒後好転 3 例 $15.8 \%$, 不変 11 例 $57.9 \%$ (良好不変 5 例, 不良不変 6 例), 惡化 5 例 26.3 $\%$ ある. 好転 3 例の $\mathrm{SM}$ 使用量法 $15 \mathrm{~g}, 16 \sim 30 \mathrm{~g}$, $31 \sim 60 \mathrm{~g}$ 各 1 例である. 遠隔成績の判明さる不変 2 例 は 2 年後惡化していた。化学療法前平均值 $44.8 \pm 15.5 \mathrm{mg}$ 
表 5 血中残余窒素と S M 量

\begin{tabular}{|c|c|c|c|c|c|c|c|c|c|c|c|c|c|c|c|c|c|c|}
\hline \multirow{4}{*}{$\begin{array}{l}S \\
M \\
(g)\end{array}$} & \multirow{2}{*}{ I } & & & \multicolumn{5}{|c|}{ II } & \multicolumn{4}{|c|}{ 群 } & \multirow{2}{*}{\multicolumn{3}{|c|}{$\frac{\text { 対 }}{a}$}} & \multicolumn{3}{|c|}{ 群 } \\
\hline & & & & \multirow{2}{*}{\multicolumn{3}{|c|}{$\begin{array}{l}a \\
10\end{array}$}} & \multirow{2}{*}{\multicolumn{3}{|c|}{$\begin{array}{l}\mathrm{b} \\
19 \\
\end{array}$}} & \multirow{2}{*}{\multicolumn{3}{|c|}{$\begin{array}{l}\mathbf{c} \\
20\end{array}$}} & & & & \multirow{2}{*}{\multicolumn{3}{|c|}{$\frac{\mathrm{b}}{15}$}} \\
\hline & \multicolumn{3}{|c|}{26} & & & & & & & & & & \multicolumn{3}{|c|}{$\frac{a}{26}$} & & & \\
\hline & 好転 & 不変 & 悪化 & 好転 & 不変 & 息化 & 好転 & 不変 & 悪化 & 好転 & 不変毘 & 悪化 & 好転 & 不変 & 悪化 & 好転 & 不変 & 悪化 \\
\hline $0 \sim 15$ & 0 & $\begin{array}{c}2 \\
(5)\end{array}$ & 0 & 1 & $\begin{array}{c}1 \\
\text { (1) }\end{array}$ & 0 & 1 & 0 & 0 & 0 & 0 & 0 & & & & & & \\
\hline $16 \sim 30$ & 4 & $\begin{array}{c}5 \\
(5)\end{array}$ & 1 & 1 & $\overline{2} \mid \overline{(2)}$ & 0 & 1 & $\begin{array}{c}2 \\
(1)\end{array}$ & 0 & 0 & $\left(\begin{array}{l}1 \\
(1)\end{array}\right.$ & 1 & & & & & & \\
\hline $31 \sim 60$ & 4 & $\begin{array}{c}\overline{5} \\
(5)\end{array}$ & 2 & 1 & $\overline{4}$ & 0 & 1 & $\begin{array}{c}8 \\
(4)\end{array}$ & 4 & 1 & $\begin{array}{c}10 \\
(10)\end{array}$ & 2 & & & & & & \\
\hline 61 以上 & 2 & 0 & 1 & 0 & 0 & 0 & 0 & 1 & 1 & 3 & $\overline{2} \mid \overline{(2)}$ & 0 & & & & & & \\
\hline 計 & 10 & $\begin{array}{c}\overline{12} \\
(12)\end{array}$ & 4 & 3 & $\begin{array}{c}7 \\
(7)\end{array}$ & 0 & 3 & $\begin{array}{c}11 \\
(5)\end{array}$ & $\left|\begin{array}{c}5 \\
{[4]}\end{array}\right|$ & 4 & $\begin{array}{c}\overline{13} \\
(13)\end{array}$ & 3 & 6 & $\begin{array}{c}19 \\
(12)\end{array}$ & 1 & 2 & $\begin{array}{c}\overline{11} \\
(8)\end{array}$ & $\overline{2}$ \\
\hline$\%$ & 38.5 & 46.2 & 25.3 & 30.0 & $|70.0|$ & 0 & 15.8 & $\mid 57.9$ & $\mid 16.3$ & $\mid 20.0$ & 65.0 & $\overline{15.0}$ & $|23.1| 7$ & $\mid 73.1$ & $\left.3.8\right|_{1}$ & 13.3 & 73.3 & 13.4 \\
\hline
\end{tabular}

ddl, 後50.5 $242.7 \mathrm{mg} / \mathrm{d} て ゙ 11.3 \%$ の增加, 高度の增加を示 した死亡の 4 例を除く之前値 $41.8 \pm 16.7 \mathrm{mg} / \mathrm{dl}$, 後值 39.4 $\pm 9.7 \mathrm{mg} / \mathrm{dl} て ゙ 5.8 \%$ の减少率となるが, 何れも有意の差 ではない. c 20例の治療前 $35.0 \mathrm{mg} / \mathrm{dl}$ 以下は12例60.0\%で 治療後好転 4 例 $20.0 \%$, 不変 13 例 $65.0 \%$ (全例良好), 惡 化 3 例 $15.0 \%$ ．好転 4 例の SM 使用量は $31 \sim 60 \mathrm{~g} 1$ 例 $61 \mathrm{~g}$ 以上 3 例である. 遠隔成績の判明せる不変の 3 例 では 1 例は 1 年後, 2 例は 2 年後何 れも不変正常值を 示した. 化学療法前平均値 $40.6 \pm 14.9 \mathrm{mg} / \mathrm{dl}$, 後 $36.3 \pm 13.2$ $\mathrm{mg} / \mathrm{dl}$ と $10.6 \%$ の诚少率がみられたが有意差ではない.

対照群：a 26例中治療前 $35 \mathrm{mg} / \mathrm{dl}$ 以下は15例57.7\%で術 後好転 6 例 $23.1 \%$, 不変 19 例 $73.1 \%$ (良好 12 例, 不良 7 例), 惡化 1 例 $3.8 \%$. 手術前平均値 $40.7 \pm 14.1 \mathrm{mg} / \mathrm{dl}$, 後 $33.3 \pm 6.0 \mathrm{mg} / \mathrm{dl}$ で10.8\%の減少率を示し, 両者の間に危 険率 $5 \%$ で有意の差が認められた. b 15例では治療前 35 $m g / d 1$ 以下 8 例 $53.3 \%$, 治療後好転惡化各 2 例 $13.3 \%$, 不
变11例73.3\% (良好 8 例, 不良 3 例) である. 治療前平 均值 $39.4 \pm 13.8 \mathrm{mg} / \mathrm{dl}$, 後 $37.0 \pm 11.8 \mathrm{mg} / \mathrm{dl} て ゙$ 前後の值に有 意の差がない.なお，群は例数少ないので省略する.

v）䋓贤尿紊クリアランス（表 6，10）I群：10例 中治療前 $70.0 \%$ 以上の正常例は 1 例 $10.0 \%$ の久で腎摘 出, 化学療法後好転せるものは 7 例 $70.0 \%$, 不変 3 例 $30.0 \%$ (何れも不良), 惡化なし. 好転 7 例の SM 使用量 は $30 \mathrm{~g}$ 以内 4 例, $31 \sim 60 \mathrm{~g} 3$ 例である. 治療前平均値 50.0 $\pm 16.2 \%$ ，後65.2 $24.4 \%$ で21.6\%の増加率を示し， 1 \%の危険率で有意差が認められる.

II 群：a 7 例中, 治療前 $70.0 \%$ 以上は 1 例 $14.3 \%$, 化 学療法後好転 1 例, 不変 6 例 $85.7 \%$ （何れも不良のも の), 惡化なし, 好転 1 例は SM60g 以上を要している. 化学療法前平均值 $66.5 \pm 8.4 \%$, 後 $69.9 \pm 17.8 \%$ で 4.9 \%の増加率を示したが, これは有意差とは云い得ない。 b 6 例では治療前 $70.0 \%$ 以上例なく, 化学療法後好転せ

表 6 総腎尿素クリアランスと S M 量

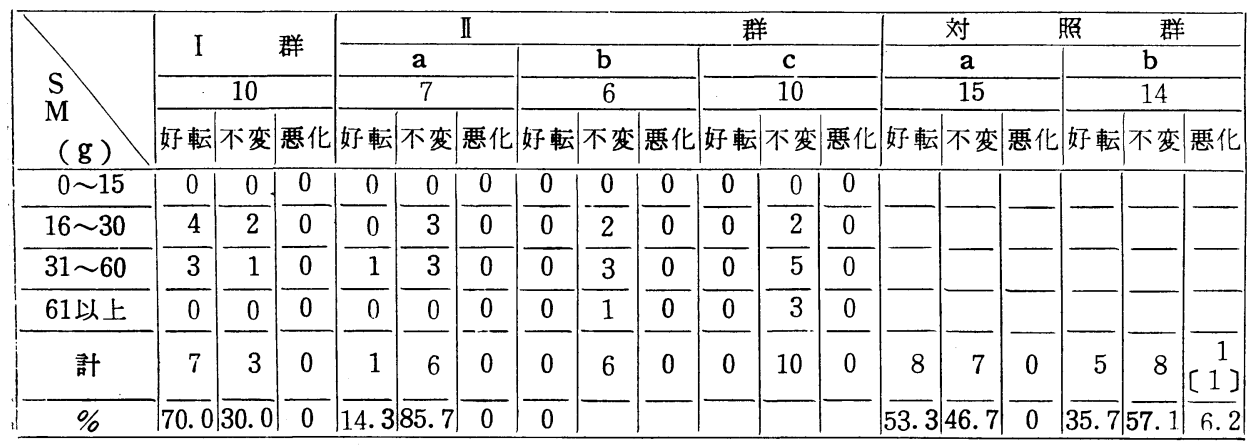

註〔]死亡例 
表 7 治療前後における水試験（機能指数）の変動

\begin{tabular}{|c|c|c|c|c|c|}
\hline 群 & S M & 数 & 前 & 後 & 增 加 率 \\
\hline \multirow{2}{*}{ I 群 } & $40 \mathrm{~g}$ 以下 & 27 & $23 . y \pm 6.1$ & $27.7 \pm 5.0$ & $13.5 \% * *$ \\
\hline & $41 \mathrm{~g}$ 以上 & 8 & $19.6 \pm 4.1$ & $21.9 \pm 6.9$ & $10.5 \%$ \\
\hline \multirow{3}{*}{$\begin{array}{l}\mathbb{I I} \\
\text { 群 }\end{array}$} & a & 10 & $27.0 \pm 3.9$ & $26.9 \pm 5.6$ & $-0.4 \%$ \\
\hline & $\mathrm{b}$ & 17 & $16.6 \pm 6.3$ & $17.0 \pm 6.7$ & $2.5 \%$ \\
\hline & c & 16 & $21.9 \pm 4.9$ & $22.8 \pm 3.9$ & $3.8 \%$ \\
\hline III & 群 & 18 & $21.5 \pm 5.1$ & $23.4 \pm 5.8$ & $8.3 \% *$ \\
\hline \multirow{2}{*}{$\begin{array}{l}\text { 対照 } \\
\text { 群 }\end{array}$} & a & 27 & $24.1 \pm 6.4$ & $29.0 \pm 5.5$ & $15.2 \% * *$ \\
\hline & $\mathrm{b}$ & 11 & $19.7 \pm 4.9$ & $21.5 \pm 4.2$ & $8.3 \%$ \\
\hline
\end{tabular}

註 $*$ 危険率 $5 \%$ 以下 $* *$ 同 $1 \%$ 以下

表 8 治療前後におけるP S P の変動

\begin{tabular}{|c|c|c|c|c|c|}
\hline 群 & S M & $\begin{array}{ll} & \text { P.S.P } \\
\text { 値 }(\%)\end{array}$ & 前 & 後 & 增 加 率 \\
\hline \multirow{2}{*}{ I 群 } & $40 \mathrm{~g}$ 以下 & 38 & $59.2 \pm 5.7$ & $61.7 \pm 5.9$ & $4.1 \%$ \\
\hline & $40 \mathrm{~g}$ 以上 & 7 & $66.0 \pm 15.8$ & $74.1 \pm 13.2$ & $10.9 \%$ \\
\hline \multirow{3}{*}{$\begin{array}{l}\mathbb{I} \\
\text { 群 }\end{array}$} & $a$ & 14 & $66.1 \pm 9.1$ & $70.3 \pm 11.8$ & $6.0 \%$ \\
\hline & $\mathrm{b}$ & 18 & $35.1 \pm 17.7$ & $35.5 \pm 21.7$ & $1.1 \%$ \\
\hline & c & 17 & $58.7 \pm 11.6$ & $60.7 \pm 9.2$ & $3.3 \%$ \\
\hline III & 群 & 10 & $62.0 \pm 9.5$ & $63.2 \pm 10.1$ & $1.9 \%$ \\
\hline \multirow{2}{*}{\begin{tabular}{l|} 
対昭 \\
群
\end{tabular}} & $a$ & 31 & $59.1 \pm 18.6$ & $66.0 \pm 15.4$ & $10.6 \% * *$ \\
\hline & $\mathrm{b}$ & 13 & $51.6 \pm 11.4$ & $55.0 \pm 10.7$ & $6.2 \%$ \\
\hline
\end{tabular}

註 $*$ 危険率 $5 \%$ 以下 $* *$ 同 $1 \%$ 以下

表 9 治療前後における血中残余窒素の变動

\begin{tabular}{|c|c|c|c|c|c|}
\hline 群 & S M & N.P.N值 & 前 & 後 & 減 \\
\hline \multirow{2}{*}{ I 群 } & 40以下 & 20 & $33.2 \pm 7.9$ & $30.9 \pm 6.6$ & $6.9 \%$ \\
\hline & 40 以上: & 6 & $44.3 \pm 12.9$ & $31.2 \pm 11.7$ & $29.6 \%$ \\
\hline \multirow{3}{*}{ II } & $a$ & 10 & $32.9 \pm 4.8$ & $29.1 \pm 4.2$ & $11.8 \%$ \\
\hline & $\mathrm{b}$ & 19 & $44.8 \pm 15.5$ & $50.5 \pm 24.7$ & $11.3 \%$ \\
\hline & c & 20 & $40.6 \pm 14.9$ & $36.3 \pm 13.2$ & $10.6 \%$ \\
\hline \multirow{2}{*}{$\begin{array}{l}\text { 対照 } \\
\text { 群 }\end{array}$} & $a$ & 26 & $40.7 \pm 14.1$ & $33.3 \pm 6.0$ & $10.8 \% *$ \\
\hline & $\mathrm{b}$ & 15 & $39.4 \pm 13.8$ & $37.0 \pm 11.8$ & $6.3 \%$ \\
\hline
\end{tabular}

註 $*$ 危険率 $5 \%$ 以下

表10 治療前後に扎ける総腎尿素クリアランスの変動

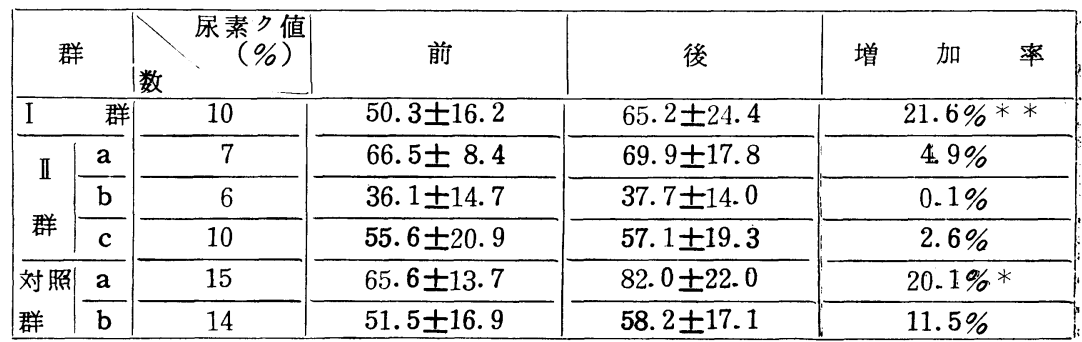

註 $*$ 危険率 $5 \%$ 以下 $* *$ 同 $1 \%$ 以下 
るものもなく, 何れも不変で, $50.0 \%$ 以下が 4 例を占め ている. SM 使用量什何れも30g 以上である. 化学療法 前平均値 $36.1 \pm 14.7 \%$, 後 $37.7 \pm 14.0 \%$ で両者の間汇有 意差惊ない. c 10例では，治療前70.0\%以上 2 例 20.0 $\%$, 化学療法後の好転例なく何れも不変で, SM 使用量 は何れも $31 \mathrm{~g}$ 以上であつた。化学療法前平均值 $55.6 \pm$ $20.9 \%$, 後 $57.1 \pm 19.3 \%$ で両者の間に有意差を認め難 w.

対照群：a 15例では治療前 70.0\%以上が 4 例 $26.7 \%$ で, 術後好転 8 例 $53.3 \%$, 不変 7 例 $46.7 \%$ (良好 4 例, 不良 3 例), 惡化なく, 術前平均値 $65.6 \pm 13.7 \%$ 亿対し後 值82.0土22.8 と20.1\%の增加率を示し，5\%の危険率で 有意差がある. b 14 例中治療前 $70.0 \%$ 以上 2 例 $14.3 \%$, 治療後好転 5 例 $35.7 \%$ ，不変 8 例 $57.1 \%$ （良好 2 例, 稍く不良 6 例), 惡化 1 例 $7.2 \%$ ある. 治療前平均值 $51.5 \pm 16.9 \%$ ，後58.2士17.1\%で11.5\%の増加率を示し たが, 有意差とは云い得ない。

\section{総括・考按}

偏腎摘出は患側, 健側の如何に拘らず尿固形成分, 体 異物性物質の排泄能に変動を生じ, 且つ残腎が代償性に 機能を増強することは周知の所であり，その程度及び期 間は腎病変の程度, 検查の種類等により必ずしも一致 しないとされている。即ち高田 ${ }^{201}$ は IC 排泄・PSP 試 験・水試験の 3 者の成績を総括して, 摘出後に於ける残 腎は排泄機能が代償性に増強されることが多いが, その 限度や時期は機能の種類によつて一定しないと述へてい る. 大塚 ${ }^{1}$ 沬多少の機能が残つている患腎の存在してい る時よりも摘出後の方が健側の IC 排泄能・総堅機能が 好転することを認め，乙れは「ネフロトキシン」の如き ものの中毒によるか, 神経作用によるか斬く措くとし ても病腎の存在は健腎機能に惡影響を与えると述べてい る. 赤松 ${ }^{211}$ 牲完成期，末期結核腎の摘出例が初期のもの に比べて腎機能が著明に増強するととを認め, とれ残 腎代償性機能元進よりも患腎による中毒性影響の消失を 重視し, 患腎病変度に関係しないと云了. 藤原 ${ }^{22)}$, 曾我 部 ${ }^{23}$ ( 腎摘出前後に抢ける腎機能を水試験・ IC 排泄・ PSP試験について比輘し, 術後16～60\%に変化を認め, 且つ旺盛期, 末期の摘出例では惡化することが少いが, 楢原 ${ }^{24)}$, 大塚，富川 ${ }^{4)}$ と同じく，同一被検者淿ても各試 験の成績は必ずしも一致しなかつたと述へている，斉 藤( 泄能障害度に概ね左右され，患腎 I C 排泄能及び尿素 クの良好のものや患腎のみの排泄障害に終るものは, 残
腎のそれに殆んど異常を認めえないと報じている．術後 の回復期間について志賀 ${ }^{25}$ 注術後 2 週間目上り総腎機能 が回復すると述べて抢り，根岸 ${ }^{3)}$ の実験的研究によれば 1 週間位で或る程度回復整調されることは明らかで, 殊 にその排泄を糸球体が司る尿酸・尿素等は術後すぐ排泄 されるが，色素剤例えば IC, PSP の如き 尿細管より排 泄されると考えられる物質は術後 1 週間では $50 \%$ 位しか 回復せず，しかもその後10カ月以上観祭してもPSP の 排泄汢それ以上注回復を及ないとされている，Glab stald $^{28)}$ は腎摘出後機能的肥大の開始は 7 14日位で 及 られ，14〜21日に於ける改善が著しいと云う．又，各機 能改善状態を治療直後と遠隔成績について比較した曽我 部 ${ }^{23)}$ の報告によると，水分排泄能は直後の好転率 $44.1 \%$ に対し遠隔では $17.6 \%$ ，濃縮は $48.1 \%$ に対し $41 \%$, IC 排 泄は $47.8 \%$ に対し $50 \%$ ，PSP 恃 $41.3 \%$ に対し $37.5 \%$ と なり, IC 排泄試験以外は治療終了直後極めて好調であ つた各機能が次第に低下を示している．な掞，手術時に 於ける麻酔の腎機能に及洔す影響は，諸家44/45)の報告に よれば特に重視する必要はないもののようである，偖， 著者は既述の如く腎結核を腎摘出兼化学療法群 (I 群) - 化学療法単独群 (II 群) 及び腎摘出 S M非併用群 (II 群) とに分け, IC排泄試験・水試験（機能指数）・PSP 試験・NPN 及び尿素クの 5 項目につき各機能の消長を 察観したので以下夫々につき従来の報告と対比検討を試 みるととにする.

\section{I 治療前後の各種堅機能並びに遠隔成績}

IC 排泄試験：病変が高度な程, 患腎は勿論, 健腎に 於いても IC 排泄障害が認められるが, 堀内 ${ }^{10}$ は IC 試 験は SM 投与により特に著明な影響を認めず，IC 排泄 機能の改善には一般に比較的長期の日数を要すると述べ ている. しかし, 岩倉 ${ }^{26)}$ は術後の機能恢復は IC 排泄 試験が最も早く, 2 週目で, $75 \%$ が術前値以上の値を示 すと云い, 斎藤 ${ }^{(4)}$, 名和田 ${ }^{15)}$ は IC 排泄能改善は尿素ク より遅れると報じている，著者例に於いても非腎摘出群 では SM 15g 以内では著明な影響が認められず， SM $30 \mathrm{~g}$ 以上使用群に改善例が稍く多くみられた。一方, 根 岸注偏腎摘出後, 機能の好転 $52.6 \%$, 惡化例 $47.3 \%$ と報 告している. 著者の場合腎摘出術施行群即与 I 及び III群 に於いては，患腎の存在している時よりも摘出後 IC 排 泄能の好転例が約57\%に認められ，根岸の成績 と一致 し, 対照aのそれと梳大差がないが化学療法単独群の20 ～35\%に比し，明ら加之を上迴つている. その後の経 過をみると図 1 の如くで, 各群とも一般に IC 排泄能の 
図 1 インヂゴカルミン排泄試験の消長

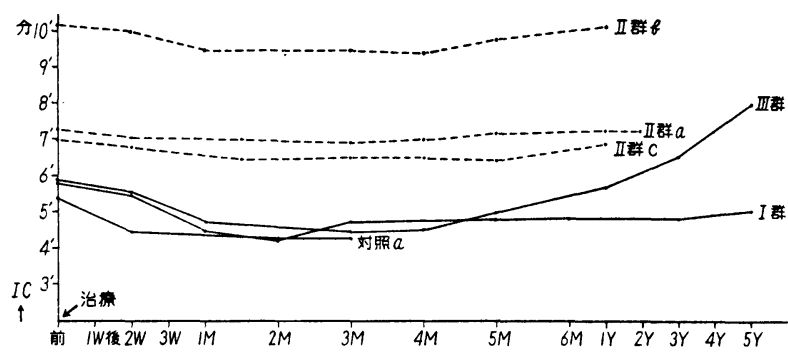

図 2 水試験（機能指数）の消長

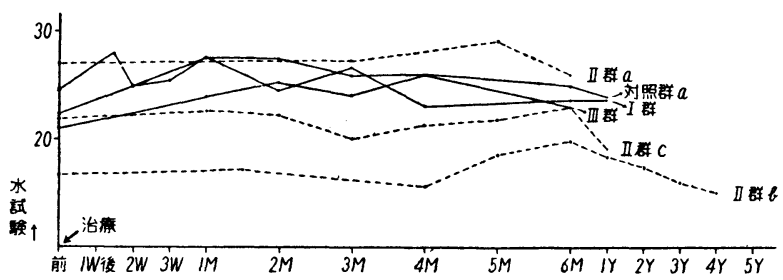

図 3 PSP 試験の消長

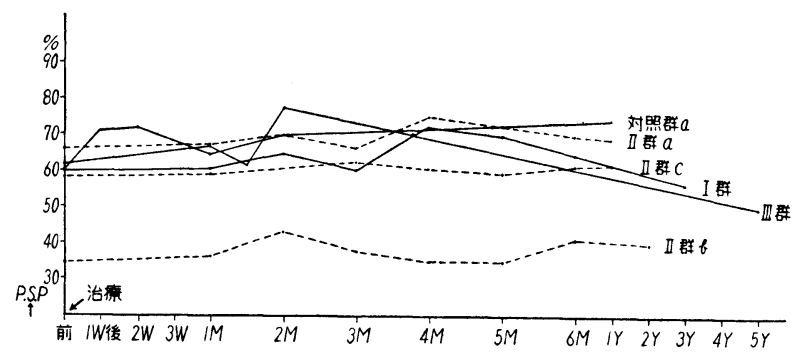

改善には長期間を要し, 概ね, 治療終了後 $1 \sim 2$ 年以上 を経てからのようである。

水試験：根岸 ${ }^{3)}$ によると水分排泄能の術後好転例が48 $\%$, 不変 $36 \%$, 恶化 $16 \%$, 又濃縮能の好転 $40 \%$, 不変 40 $\%$, 惡化 $20 \%$ とされ，著者のI群に於ける好転 $48.6 \%$, 不変 $42.9 \%$, 惡化 $8.5 \%$ は概㱛乙れと一致して抢り，乙 の好転率を II 群及び対照 $\mathrm{a}$ は大差がないが, 化学篁法単 独のII群のそれより明らかに高率となつている，又，著 者の場合 S M投与量からみれば31 60g で好転が最も 多い. その後の経過は図 2 に示すように摘出群 (化学療 法非併用群も含む）では治療終了後概ね $2 \sim 3$ 力月が機 能最も好調であるが，4 力月以降はそれ以上の改善の傾 向がなくむしろ下降, しかし略く一定の機能を保つてい る.これに対して化学療法単独群では機能好転は稍て遅 れて $5 \sim 6$ カ月後にみられるが, その程度は前者に比し て余り著明でなく, それ以後は次第に下降一途の傾向を
示す．即ち，I 群， II群及び対照群 $\mathrm{a}$ の如く腎摘出術の 対象となつたものでは治療により機能に著明な好影響を 認め, II群 a, b, c の如く化学療法のみの場合はその影 響は必ずしも著明ではない。

PSP 試験：三輸27) PSP 15分値 は腎血浆流量上高 度の相関を有し，腎循環障害並びに尿細管機能状態の 指標となると述べている．根岸は術後 $70 \%$ 以上を呈し たもの68\%と報告し, Herman ${ }^{29)}$ は SM 単独にて 66.6 \%に好転をみたと云う。野見山年仙 $\mathrm{SM}$ (35g), PAS （238g）併用にて $69.2 \%$ の好転， $30.8 \%$ の惡化を認 め, SM, TBI 併用以 SM+PAS, SM 単独よりむしろ 下迴わつていると報告し，著者の場合 2 時間值の比較で あるがI群即ち腎摘出術・SM併用が最も好転例が多く， $42.2 \%$ を占め，諸家のそれを幾分下迴わる如き成績であ り，正常值にまでは完成恢復をみない。な扮，SM 量か らみれば, $61 \mathrm{~g}$ 以上投与しても好転のみられない場合は 
図 4 血中残余窒素の消長

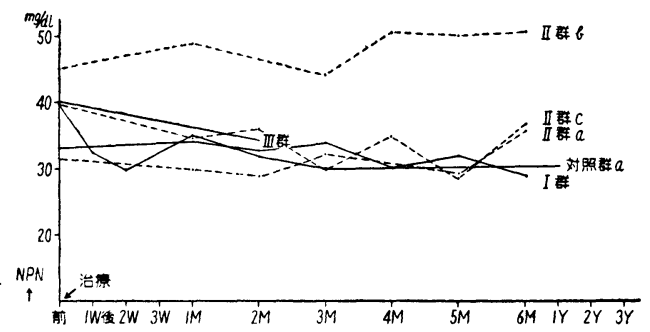

図 5 総腎尿素クリアランスの消長

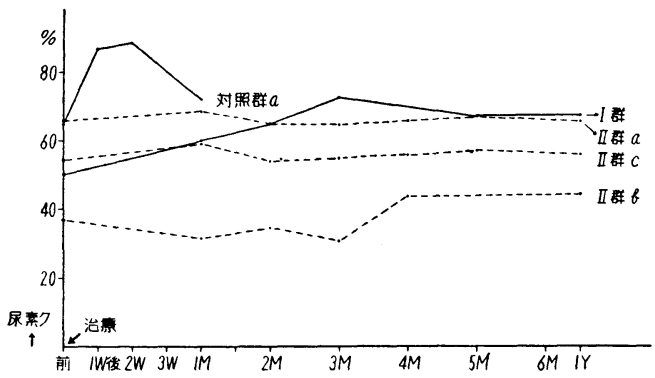

概ね機能改善は期待出来ないもののようである. その後 の経過は図 3 に示した. 即ち一般に $2 \sim 4$ 力月後が最高 值, 以後下降の傾向を示し芯. な招, 化学療法単独群 $b$ では動摇を示し乍らも 4 力月以後かなり長く改善された 良好機能が維持されているようである. しかし対照 $\mathbf{a}$ 程 著明でない。

NPN : 腎機能障害が 初期〜中等度の 場合代償性多尿 或いは蛋白摄取の制限により血中残余窒素蓄積が防止せ られるため, その値は正常範囲内に止まり, 腎機能障害 の存在を知り得ないととが多い. 従つて本検查は中等度 以上の腎機能障害時に臨床的価値があるとされている が, NPN 改善状態をみると, 腎摘出, S M併用のI群 が化学療法単独の II 群及び対照群に比して好転率が幾分 高い傾向にあるが, 有意の差を示すには至らない. その 後の経過をみると, 図 4 亿示すように, II 群 $\mathrm{b}$ 以外は治 療終了後 2 週〜 1 力月ょり減少し始めているが, その後 化学療法単独群では次第に上昇, 治療前の值を上廻わる 如き傾向を示すのに対し, 腎摘出群では一般に低值を維 持する如き経過を見せている.

尿素ク：総堅尿素クは富川, 原 ${ }^{9}$, 斎藤 ${ }^{14)}$ 等によると NPN より敏感であるとされているが, 著者の場合I 群 に於ける尿素クの好転率は70\%を示し，対照群とは必 ずしも有意差を認めるに至らないが, II 群のそれを明
らかに上迴わつている. 即ち化学療法のみの群では著明 なる好影響を認め得ない，その後の経過をみると図 5 に 示す如くで, 観察期間も長くないが, I 群は治療後 3 力 月で著明な上昇改善, 以後下降の傾向を示したが, 治療 前に比べると高値が維持され, 治療による好影響と考え られる.しかしII群では上昇は一時的で, しかもその程 度は少なく, 以後次第に下降, むしろ治療前の成績を下 趈わるような傾向にある。

次に遠隔成績調査時に於ける各検查結果を数例の少な い群は除いて, 治潦終了直後の変動状態と比較し, これ を機能惡化及び非惡化（更に好転或いは不変現状維持） の 2 群に分けてみると IC 排泄能に関してI 群直後成績 は惡化 $5.7 \%$ (6 例) に対し $1 \sim 6$ 年後結果の判明せる 16例の惡化は $15 \%$, II 群 cでは直後惡化 $6.7 \%$ (1 例) に対し $1 \sim 6$ 年後の 6 例が全例惡化, 囟群では直後惡化 $5.3 \%$ ( 1 例), $5 \sim 10$ 年の 8 例では惡化 $37.5 \%$, 対照 a では直後惡化 $12.5 \%$ （4 例）に対して 3 カ月〜 1 年後の 5 例では $20 \%$ が惡化（死亡）している. 水試験では I 群 の直後機能惡化例 $8.5 \%$ ( 3 例) $2 \sim 3$ 年後の 6 例に於 ける成績では惡化 $25 \%$ ，II群 b の直後惡化 $11.8 \%$ ( 2 例) に対して $2 \sim 3$ 年後の 6 例では惡化 $50 \%$ ， II 群直後惡 化 $11.1 \%$ （2 例）に対し $5 \sim 11$ 年の 4 例では矢張り惡化 $50 \%$, 対照 $\mathrm{b} て ゙ は$ 直後惡化例なく， 3 カ月〜 1 年後調査 せる 5 例中にも惡化例はない. PSP では I 群の直後惡 化例 $2.3 \%$ ( 1 例), $3 \sim 4$ 年後の 7 例では惡化 $42.8 \%$, I 群では直後惡化 $10 \%$ ( 1 例), $5 \sim 11$ 年後の 2 例は共に惡 化間もなく死亡している．NPN では I 群直後惡化例 $15.3 \%$ ( 5 例) 3 年後の 3 例は全て惡化をみない. II 群 b では直後惡化 $26.3 \%$ ( 5 例), 2 年後の 2 例は共に惡化死 亡, II 群 c では直後惡化 $15 \%$ ( 3 例), $1 \sim 2$ 年後の 3 例 では全例惡化をみている. 以上の如く, 各種腎機能の変 動は腎結核各群を通じて治療終了直後に比して遠隔成績 では惡化例が明らかに増加, 機能良好例減少の傾向を示 しており, 畺我部 ${ }^{23)}$ の観察に略一致するが, NPN の及 は両者の間に有意差を認めるに至つておらない.なお, 腎摘出術, 化学療法併用群では腎摘出術化学療法非併用 群或いは, 化学療法単独群に比し, 治療打切り後の惡化 例の増加㑯向が著明でなく, 各機能の遠隔成績もかなり 良好に保たれているものと推測される。一方, 対照群て は近接成績と遠隔成績とで腎結核に於ける如き差異は指 摘されない(表略).

SM 投与量: 各種機能改善に要した SM の量的関係 を $15 \mathrm{~g}, 16 \sim 30 \mathrm{~g}, 31 \sim 60 \mathrm{~g}$ 及び $61 \mathrm{~g}$ 以上の 4 段階に 
分けて整理すると IC 排泄試験では, I 群及びII 群 $\mathrm{a}, \mathrm{b}$ では30g 投与例の好転率が最もよく, それ以上 $\mathrm{SM}$ 量 が增加しても，機能改善は必ずしも促進されないように 思われる. 然しII群 $\mathrm{c}$ 即ち残腎結核では60g まで達した 例の方が好転率が高い: 其他水試験, PSP, NPN, 及び 尿素クも同様の傾向が認められるが，一般に IC 排泄能 に比べて機能改善はより多くの SM を要するものの如 くである(表略).

\section{II 尿所見及び結核菌の消長と堅機能との関係}

堀内 ${ }^{(0)}$ は腎機能が良好な程, 尿所見の改善が著明であ ることを述べているが，尿所見の改善に関しては，溷濁 - 膿球・蛋白の各項について治療後, 2 種類以上が改善 されたものを好転とすれば IC 排泄試験, 水試験, PSP 試験，NPN, 尿素クとの関係は表12 亿示す如くである. 即ち治療により尿所見に改善の認められた群は非改善群 に比し一般に各機能共良好となつているが有意差を認め るに至らず，特に II 群 b即ち両側性腎結核では SM投与 により著明に機能改善がみられた際でも，尿所見の改 善は必ずしもこれに伴わない. この点は既に教室荒川 が指摘せる所と一致している. 次に結核菌の消長を吟 味するとI 群48例中腎摘出術, SM 併用療法終了後結核 菌を証明せるものは 7 例14.6\%で，乙の中，先述の基準 に従つて腎機能良好と判定されたもの 5 例, 不良 2 例と なつている. II 群a 14例中化学療法後菌陽性は 3 例で何 れも腎機能は良好である. b 即ち両側性の 20 例では化学 療法後菌陽性16例で，つち15例は腎機能改善が認められ ない. c 17例中化学療法後菌陽性 2 例で, 腎機能良好, 不良各 1 例となつている. III群20例では術後菌陽性 6 例 で半数の 3 例は书機能良好であり, 552 例は 5 年後と 11 年後再び菌証明され機能は何れも惡化していた。. 以上 の如く治療後菌陽性でも, 腎機能良好例もあり, 又菌陰 性でも腎機能不良例があり，菌陰性化と腎機能改善とは 必ずしも一致せず，化学療法を行なつた腎機能良好例に 耐性菌出現をみたものが数例あつたととは注目される
(表略).

\section{III 各程肾機能相互関係}

各種検查成績が必ずしも一致しないととは既に諸家の 指摘する所であるが，原(5) は尿素ク値と同時に行なつた PSP 排泄試験, 水試験, 血中尿素量及び NPN との間 に何れも相関々係を認め, 摘出前後に於ける尿素クを PSP ( 1 時間値) は略と一致していることをのべ, 斎 藤 ${ }^{14)}$, 名和田 ${ }^{15}$ ) IC 排泄試験 と総腎尿素クとは残腎結 核に於いて概ね平行し, 尿素クと血中 NPN とは両者 相関連しつ>変動することを述べ, 岩倉 ${ }^{26)}$ は濃縮機能, 稀釈機能と血中クレアチニンとは高度の機能不全の場合 のみ一致するとし, 大島 ${ }^{31{ }^{132} \text { ) }}{ }^{2} \mathrm{PSP} 15$ 分值と RPF, RBF とが比較的よく平行するととを認めている. 尿素クと各 種腎機能のSM 使用前後に於ける相互関係については未 だ報告に接しないが，著者の観察によればしれらは夫々 表11, 図 6 の如くになる. 即ちI群では尿素クは治潦 前, 水試験機能指数, PSP 及び NPN とは何れも相関 が少ないが, 腎摘出・SM 使用後, 機能指数とは順, NPN と注逆の有意の相関が夫々認められた. II 群 aで は SM 使用前後共, 尿素クと機能指数は正の, NPN と は逆の夫々有意の相関があり, PSP との相関は少ない. $\mathrm{b}$ 及び $\mathrm{c} て ゙ は \mathrm{SM}$ 治療前後共, 尿素クと水試験, PSP は夫々有意の順相関, NPN とは有意の逆相関が認めら れた. III群では腎摘出術施行前の成績を欠いているが, その後尿素クと水試験, PSP は有意の順相関, NPN と は有意の逆相関を示している. 以上の如く, 各群により 各種腎機能の回復の状態乃至程度が必ずしも一致せず, 姉妹腎の代償機能其他の因子が介在するためと推察され る.

\section{IV 各種督機能の各群間比較}

各種腎機能の改善状態が必ずしも一致しないととは前 項に於いても明らかにされているが, 水試験, PSP, NPN 及び尿素クについて, 治療後に於ける各群間の成績を 吟味すると, 表 13 の如く要約される. 即 ち先ず各群間

表11 治療前後における各種堅機能相互関係

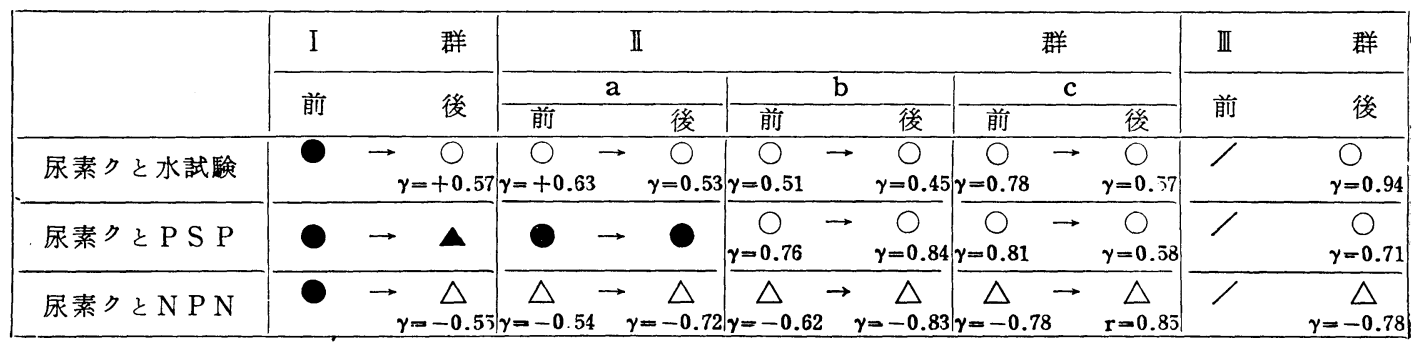


図 6 a) 尿素クと水試験（I 群）

$\bigcirc \mathrm{S} \mathrm{M}$ 使用前 $(\gamma=0.28)$

S M 使用後 $(r=0.57)$ b) 尿素クと P S P ( I 群)

$\bigcirc \mathrm{SM}$ 使用前 $(\gamma=0.15)$

S M 使用後 $(\gamma=-0.02)$ c）尿素クと N P N ( I 群)

$\bigcirc \mathrm{S} \mathrm{M}$ 使用前 $(\gamma=\mathrm{N} 0.21)$

$\mathrm{S}$ M使用後 $(r=-0.55)$
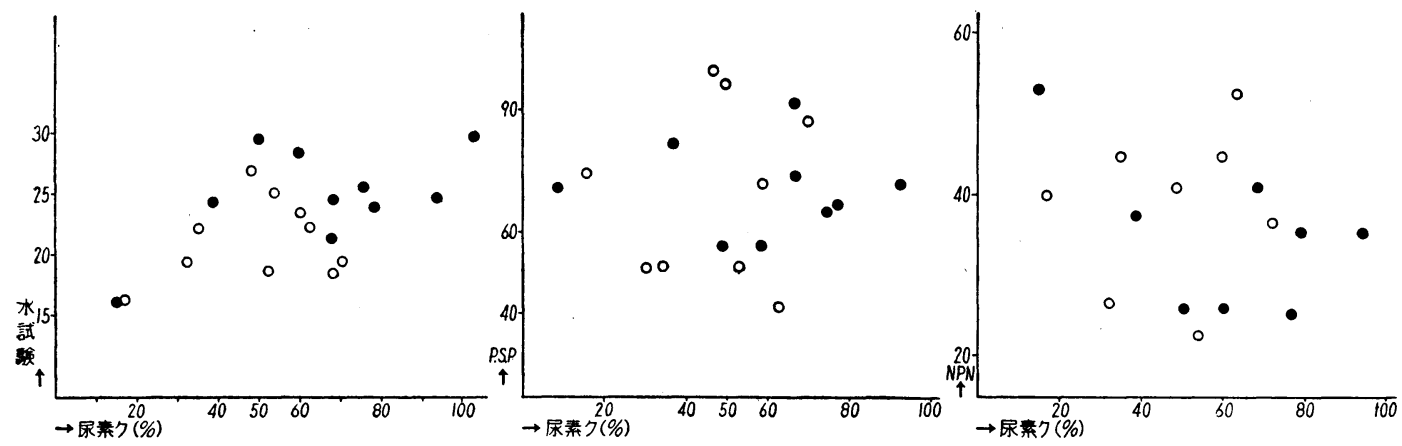

d）尿素クと N P N (II 群 b )

$\bigcirc \mathrm{S} \mathrm{M}$ 使用前 $(\gamma=-0.62)$

$\mathrm{S}$ M使用後 $(r=-0.83)$

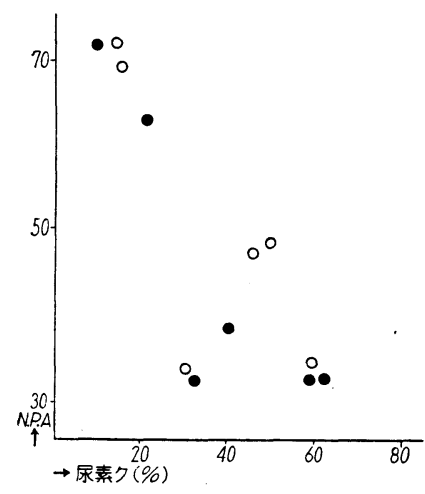

e）尿素クと水試験（II群 c) S M 使用前 $(\gamma=0.78)$ S M 使用後 $(\gamma=0.57)$

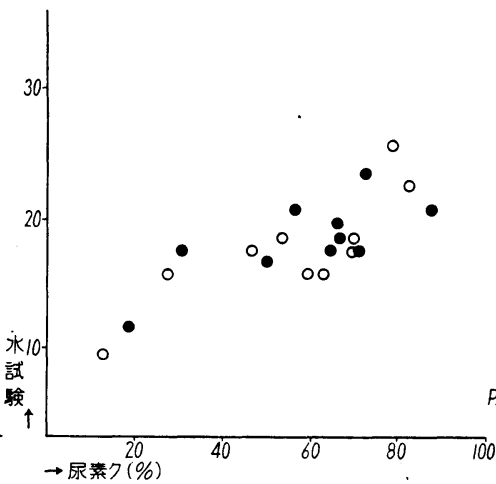

f）尿素クと P S P (II群 c)

$\bigcirc \mathrm{S} M$ 使用前 $(\gamma=0.81)$

S M 使用後 $(r=0.58)$

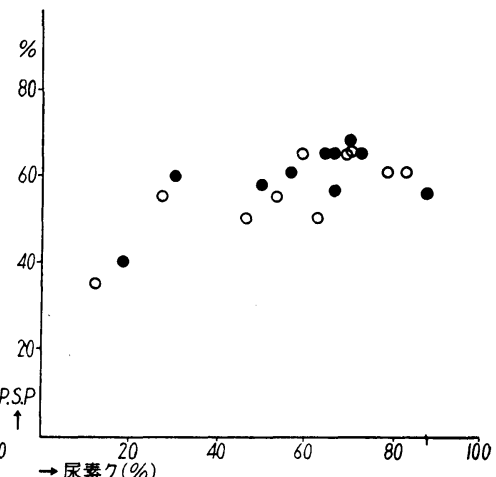

g) 尿素クと N P N (II 群 c )

$\bigcirc \mathrm{S} M$ 使用前 $(\gamma=-0.78)$

S M 使用後 $(r=-0.85)$

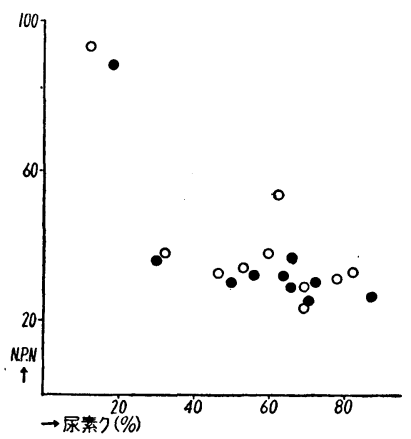


表12 尿所見好転群と非好転群に於ける腎機能比較

\begin{tabular}{|c|c|c|c|c|c|c|}
\hline \multicolumn{2}{|c|}{ 群 } & 尿所見 & 水試験(機能指数) & P S P 試 験 & 血 中残 余窒素 & 尿素クリアランス \\
\hline \multirow{2}{*}{$\mathrm{I}$} & \multirow{2}{*}{ 群 } & 好 転 & $28.3 \pm 4.8$ (22例) & $69.4 \pm 13.2 \%$ (29例) & $30.7 \pm 5.7 \mathrm{mg} / \mathrm{dl}(21$ 例 $)$ & $72.5 \pm 20.3 \%$ ( 7 例) \\
\hline & & 非好転 & $23.4 \pm 7.9$ (13例) & $58.2 \pm 5.3 \%$ (18例) & $\overline{34.2 \pm 14.1 \mathrm{mg} / \mathrm{dl} \text { (12例) }}$ & $48.1 \pm 25.9 \%$ ( 3 例) \\
\hline \multirow{4}{*}{ II } & \multirow{2}{*}{$\mathrm{a}$} & 好 転 & $30.0 \pm 3.1$ ( 5 例) & $74.0 \pm 6.2 \%$ (8例) & $29.3 \pm 4.8 \mathrm{mg} / \mathrm{dl}(7$ 例 $)$ & $75.9 \pm 17.3 \%$ ( 4例) \\
\hline & & 非好転 & $23.8 \pm 5.7$ (5 例) & $72.0 \pm 6.9 \%$ ( 4例) & $30.6 \pm 3.8 \mathrm{mg} / \mathrm{dl}(4$ 例 $)$ & $61.9 \pm 14.8 \%$ ( 3 例) \\
\hline & \multirow{2}{*}{ b } & 好 転 & $(0)$ & $(0)$ & $(0)$ & $(0)$ \\
\hline & & 非好檕 & $\overline{17.1 \pm 6.7 \text { (16例) }}$ & $38.4 \pm 24.2 \%$ (19例) & $\overline{58.5 \pm 41.4 \mathrm{mg} / \mathrm{dl} \text { (19例) }}$ & $37.7 \pm 21.3 \%$ ( 6 例) \\
\hline \multirow[t]{2}{*}{ 群 } & \multirow{2}{*}{ c } & 転 & $25.6 \pm 4.8$ (9例) & $67.0 \pm 10.9 \%$ ( 9 例) & $29.3 \pm 5.7 \mathrm{mg} / \mathrm{dl}$ ( 9 例) & $69.9 \pm 11.6 \%$ ( 5 例) \\
\hline & & 非好転 & $\longdiv { 2 0 . 7 \pm 3 . 8 ( 7 \text { 例 } ) }$ & $58.6 \pm 10.5 \%$ ( 8例) & $41.8 \pm 22.8 \mathrm{mg} / \mathrm{dl}(7$ 例 $)$ & $44.3 \pm 18.6 \%$ ( 5 例) \\
\hline \multirow{2}{*}{ III } & \multirow{2}{*}{ 群 } & & $25.9 \pm 6.3(5$ 例 $)$ & $66.5 \pm 12.1 \%$ ( 2例) & $30.0 \pm 5.8 \mathrm{mg} / \mathrm{dl}$ ( (1例) & $79.5 \pm 23.3 \%$ ( 1例) \\
\hline & & 非好転 & $22.5 \pm 5.9$ (13例) & $60.7 \pm 12.8 \%$ ( 8例) & $41.7 \pm 13.3 \mathrm{mg} / \mathrm{dl}$ ( 3 例 $)$ & $53.8 \pm 15.5 \%$ ( 3 例) \\
\hline \multirow{4}{*}{$\begin{array}{l}\text { 対 } \\
\text { 照 } \\
\text { 群 }\end{array}$} & \multirow{2}{*}{ a } & & $28.1 \pm 6.4$ (19例) & $70.5 \pm 17.0 \%$ (22例) & $30.8 \pm 5.6 \mathrm{mg} / \mathrm{dl}$ (18例) & $88.7 \pm 23.2 \%$ (11例) \\
\hline & & 非好転 & $23.1 \pm 7.2(7$ 例 $)$ & $64.4 \pm 19.1 \%$ ( 7 例) & $36.0 \pm 6.9 \mathrm{mg} / \mathrm{dl}(7$ 例 $)$ & $63.9 \pm 13.0 \%$ ( 4 例) \\
\hline & \multirow[t]{2}{*}{ b } & 好 転 & $26.4 \pm 5.4$ (5例) & $60.0 \pm 13.1 \%$ ( 3 例) & $27.3 \pm 14.2 \mathrm{mg} / \mathrm{dl}(2$ 例 $)$ & $70.1 \pm 19.6 \%$ ( 2例) \\
\hline & & 非好転 & $22.3 \pm 4.4$ (9例) & $55.4 \pm 12.8 \%$ (11例) & $37.1 \pm 18.4 \mathrm{mg} / \mathrm{dl}$ (12例) & $58.9 \pm 17.5 \%$ (12例) \\
\hline
\end{tabular}

表13 各群間に於ける治療後腎機能改善率比較

\begin{tabular}{|c|c|c|c|c|c|c|c|c|c|c|}
\hline & 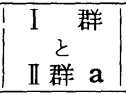 & $\begin{array}{ccc} & \text { 群 } \\
& \text { そ } & \\
\text { II } & \text { 群 } & \text { b }\end{array}$ & 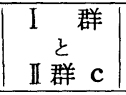 & $\begin{array}{l}\text { I 群 } \\
\text { III }\end{array}$ & $\begin{array}{c}\mathbb{I} \text { 群 } \mathrm{a} \\
と \\
\mathbb{I} \text { 群 } \mathrm{b}\end{array}$ & $\begin{array}{c}\text { II 群 } \mathbf{a} \\
と \\
\text { II 群 } \mathbf{c}\end{array}$ & $\begin{array}{l}\text { II 群 } \mathrm{a} \\
\text { と } \\
\mathbb{I I I}\end{array}$ & $\begin{array}{c}\mathbb{I} \text { 群 } \mathrm{b} \\
と \\
\text { II 群 } \mathrm{c}\end{array}$ & $\begin{array}{l}\text { II 群 } \mathrm{b} \\
\text { と } \\
\text { III 群 }\end{array}$ & $\begin{array}{c}\text { II 群 } \mathrm{c} \\
\qquad \\
\text { III 群 } \\
\end{array}$ \\
\hline 水試験 & $\mathrm{P}<0.05$ & $\mathrm{P}>0$ & $\mathrm{P}>0$ & $\mathrm{P}<$ & $\mathrm{P}>0.01$ & $\begin{array}{c}0.05<1 \\
\mathrm{P}<0.01\end{array}$ & $\mathrm{P}<0.05$ & $\left|\begin{array}{c}0.05<1 \\
P<0.01\end{array}\right|$ & $\mathrm{P}>0.01$ & $\mathrm{P}<0.05$ \\
\hline P S P & $\mathrm{P}<0.05$ & $\mathrm{P}>0.01$ & $\mathrm{P}<0.05$ & $\mathrm{P}<0.05$ & $\mathrm{P}>0.01$ & $\mathrm{P}<0.05$ & $\mathrm{P}<0.05$ & $P>0.01$ & $\mathrm{P}>0.01$ & $\mathrm{P}<0.05$ \\
\hline N P N & $<0.05$ & $\mathrm{P}>0.01$ & .05 & 05 & $\mathrm{P}>0.01$ & $\mathrm{P}<0.05$ & $\begin{array}{r}0.05< \\
P<0.01\end{array}$ & $\mathrm{P}<0.05$ & $\mathrm{P}<0.05$ & $\mathrm{P}<0.05$ \\
\hline 尿 & $\mathrm{P}<0.05$ & 1 & F & & $>0.01$ & $<0.05$ & $\mathrm{P}>$ & .05 & $\left|\begin{array}{r}0.05< \\
P<0.01\end{array}\right|$ & 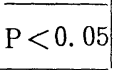 \\
\hline
\end{tabular}

此較に於ける 10 種類の組合せで, 有意差が最も屡々認め られたのは水試験で，次いで PSP となり，NPN，尿素 クでは有意差を示すととが比較的少ない。次に各群間 の比較では I 群とII 群 $\mathrm{a} ，$ I 群とIII群，及び正群とII群 c とでは各種機能に有意差を指摘することが出来ず，乙 れはごく初期の偏側腎結核では腎機能がかなりょく保た れて捛るためもあろろが化学嘹法のみで, 腎摘出兼化学 療法に匹敵する効果を挙げ得る可能性を示し, 腎摘出術 が正しい適応の許に行なわれるならば, 化学療法併用の 場合に劣らぬ効果の期待出来るとと或いは, 残腎結核に 対する SM 療法の効果渻結核に対する従来の腎摘出 術と大差のないとと等を示唆する成績と考えられる。一 万, I 群とII 群 $\mathrm{c}$ とでは水試験, II 群 $\mathrm{a}$ とIII群では NPN の改善の程度に有意差が認められ, 腎摘出術と化学療 法との差異がある程度賽われ，II群 $\mathbf{a}$ と同 $\mathrm{c}$ とでは水試 験, II 群 $\mathrm{b}$ と同 $\mathrm{c}$ では, 水試験及び PSP, II 群 $\mathrm{a}$ と同 $\mathrm{b}$ では 4 種機能全ての改善状態に夫々有意差がみられた. 即ちこれは同じく化学療法を施しても腎結核の病期, 病
勢により，効果に差異のあるととを腎機能の面より示す ものであり, 更に I 群とII 群 bでは矢張り 4 種機能全て

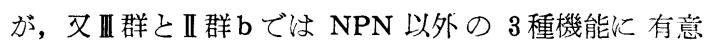
差が指摘され, これは両側腎結核( II 群 b) 飞対する化学 療法単独の効果は腎摘出術兼 SM 療法或い沙督摘出, 非 SM 併用のそれよりも下迴るととを意味して抢ると 考えられる。な拉督摘出群 (化学療法併用を含む) と非 摘出群 (化学療法の及) のとに分けてみると, NPN 以 外 IC, 水試験, PSP, 尿素クでは何れも前者に於いて 改善状態が明らかに顕著であり, 何れにしろ化学療法の 限界を一応推測せしめる成績である.

\section{$\mathbf{V}$ 腎機能総合成綡}

以上各種検查事項につき種々の角度より検討を加えた が, 上述 5 種類の検查成績を総合して 2 種類以上改善 のみられたものを腎機能好転，2 種類以上惡化したもの を腎機能惡化と見做し, 各群に於いて治療による影響を 遠隔成績を含めて整理すると次のようになる(表略). 即 与, I 群48例では好転 25 例 $52.1 \%$, 惡化 3 例 $6.3 \%$ (内 
3 年後 1 例， 4 年後 1 例，治療中 1 例),不変 20 例 $41.7 \%$ (变好不変 16 例, 不良不変 4 例). II 群a 14例中好転 5 例 $35.7 \%$, 惡化 2 例 $14.2 \%$ ( 5 年後 1 例, 治療中 1 例), 不 変 7 例 $50 \%$ (何九も良好). II 群 b 20 例中好転 4 例 20.0 $\%$, 不変 10 例 $50.0 \%$ ( 9 例䏠不変不良), 惡化 6 例 $30.0 \%$ (入院治療中死亡 4 例). II 群 $\mathrm{c} 17$ 例中好転 2 例 $11.8 \%$, 不変 15 例 $88.2 \%$ (不良 2 例), 惡化なし. III群 19 例中好転 7 例 $36.8 \%$, 不変 12 例 $63.2 \%$ (不良不変 2 例, 他は良好 不変),遠隔成績では惡化 2 例となつている. 次に対照群 a 34 例中好転 20 例 $58.8 \%$, 不変 12 例 $35.3 \%$ (良好 9 例,

不良 3 例), 惡化 2 例 $16.9 \%$ である. b 16例では好転 3 例 $18.7 \%$, 不変 11 例 $68.7 \%$ (不変不良 1 例他㟍好), 惡化 2 例 $12.6 \%$ となる. 従つて, 腎摘出術兼化学療法群の好 転率上化学療法単独群及び腎摘出術・SM 非併用群のそ れと比べると, 先ずII 群 $\mathrm{a}$ 即ち初期偏側性では有意差と 牥云い難いが, 両側及び残腎では有意差を示し, II 群全 体として (51例中 11 例 $21.5 \%$ ), 明らかに有意差が認めら れるが，後者とは必ずしも然らず，即ち腎摘出群では非 結核性疾患を含めて一般に非摘出群に比べて腎機能好転 率え゙かなり高いととが䂓知された。勿論，現在に於ける SM の投与法には再検討を要する余地が残されており, 一方長期 SM 投与により尿管狭窄乃至閉塞を生じ， 2 次的に高度の腎水腫・膿腎或いは所謂閉塞性腎結核を来 し，腎機能を更に低下することは既に諸家 ${ }^{33)}$ ３8）の指摘 ずる所であり，かかる場合流化学療法に頼らず出来得る 限り摘出して全身への影響を防ぐべきことは言を俟たな い. 堀内 ${ }^{10)}$ 泣 IC と静脈性排泄機能が比較的良好な症例 で汸化学療法により空洞壁の清浄化, 上皮再生, 類上皮 細胞の萎縮等の変化が明らかであるが，機能低下の場 合，抗結核剤が病変部に浸透しないため奏効しがたくな

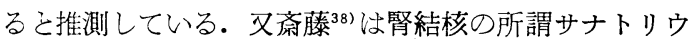
么療法は, ある程度の改善が認められるが血液化学的方 面から結局腎摘出術に数段劣り, 化学療法開始後 $3 \sim 6$ カ月以後は病勢の進行を停止するのみでそれ以上の改善 は認められないと云う．化学療法を単独施行せる腎結核 に於ける腎機能は腎摘出群に比べて各検查の好転率が低 く，化学療法による尿所見の改善は腎機能のそれと必ず しす平行せず，且つ腎機能が中等度以上障害あるもので 心耐性菌の早期出現や尿管狭窄等のみられるととは上記 の通りであり, 又治療前後に於いて, 各種腎機能の改善 状態に有意差の認められたのは既述の如く，水試験では I 群 (SM 投与量 $40 \mathrm{~g}$ 以下), III群, 対照 a, PSP • NPN では対照 $\mathrm{a}$ ，尿素クでは I 群及び対照 $\mathrm{a}$ と何れも腎摘出
術の施行された群のみであることは甚だ注目され，本 邦では，化学療法のみで腎結核の殆んど総ての症例を治 し得ると考えている人はないと云う大越(0)の調查成績の 首肯される所以でもある. な抢, 腎摘出術兼化学潦法併 用群之腎摘出術の及の群乃至化学潦法単独群と比べて各 検査成績の間に有意の差を認めなかつたが，遠隔成績に て前者に機能惡化例の比較的少なかつたととは, SM 併 用による手術適応の拡大, 両側性腎結核或いは進行せる 残腎結核に対する適応等と共に化学療法の必要性を示寸 資料と考えられる.

\section{附） 肝機能及び血圧との関係}

肝臓と腎缄とは密接な関係を有していることは言を俟 たない. 即ち斎藤 399 は両機能の並行することを認め, 尿素 ク低下例では常に肝障害を伴うと述べている. 又安原 ${ }^{411}$ 等は各種泌尿器疾患の化学療法, 手術の各種肝機能検査 成績に対する影響を検して, 血清コバルト反応, ウェル トマン反応では最初短縮, その後正常乃至延長, 血清高 田反応は SM投与により軽度或いは中等度の陽性を示す が，手術による影響は認められないとしている，富川4 によれば腎病変が高度となるにつれて, 肝機能障害が増 し, 手術によつて肝機能も好転するてとが観察されて掠 り, 肝機能は督病変による 2 次的影響を受けると考えら れる.

著者の場合肝機能を尿中ウロビリノーグン，血清高田 反忍及び BSP 試験の 3 者併用により 綜合的に判定, 1 . 種類の內陽性を (十), 2 種類陽性を (H), 3 者陽性を (卅)として治療前後に於ける腎機能との関係を、吟味す ると表14の如くになる。即与，治療前に肝障害の証明さ れたものは、, II 群 b $60 \%$, II 群 $20 \%$, II 群 c $11.7 \%$, I 群10.4\%, 対照 b (腎炎) $37.5 \%$, a 14.7\%の順で合阡 34 例となるが, 一II群 $\mathrm{a} て ゙ は$ 肝障害は 1 例も認められなか つた.な掞，乙れらは何れも程度の差はあるが，腎機能 障害が同時にみられ，一般に腎病変の高度のもの，両側 性のもの程, 肝機能障害も高度となつて抢り, 殊に尿素: ク 40\%以下の例は全て肝障害が指摘された. 治療後の成 績をみると18例 $52.9 \%$ は肝機能障害の恢復乃至好転をみ て㧍り，それを肝機能障害の程度によつて比較すると (十)群14例の好転率71.4\%に対し（H）～（卅）群のそ れは $40 \%$ 之幾分低く, 又腎結核群の好転率 $43.4 \%$ に対し 対照群のそれは72.7\% と後者が稍く前者を上廻る如き成 績であるが例数も少く何れも有意差とは云い難い。腎結 核では腎摘出術兼化学療法及び腎摘出術のみの群の肝機 能好転率 $66.6 \%$ に対し，SM 単独群のそれは $28.5 \%$ でて 
表14 盰機能と堅機能

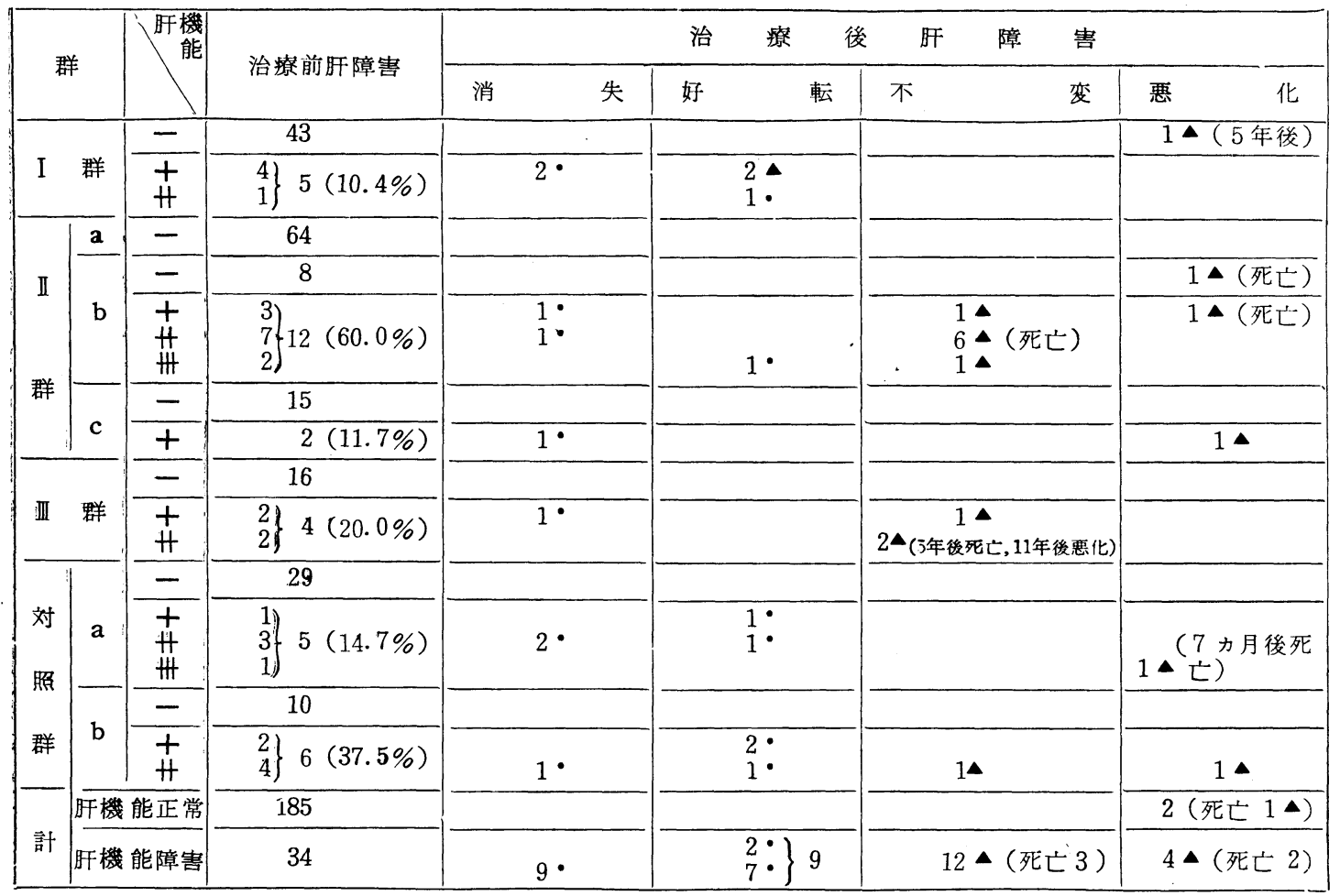

註 ○腎機能好転例， $\boldsymbol{\Delta}$ 同不良例

表15 治療後血圧変動

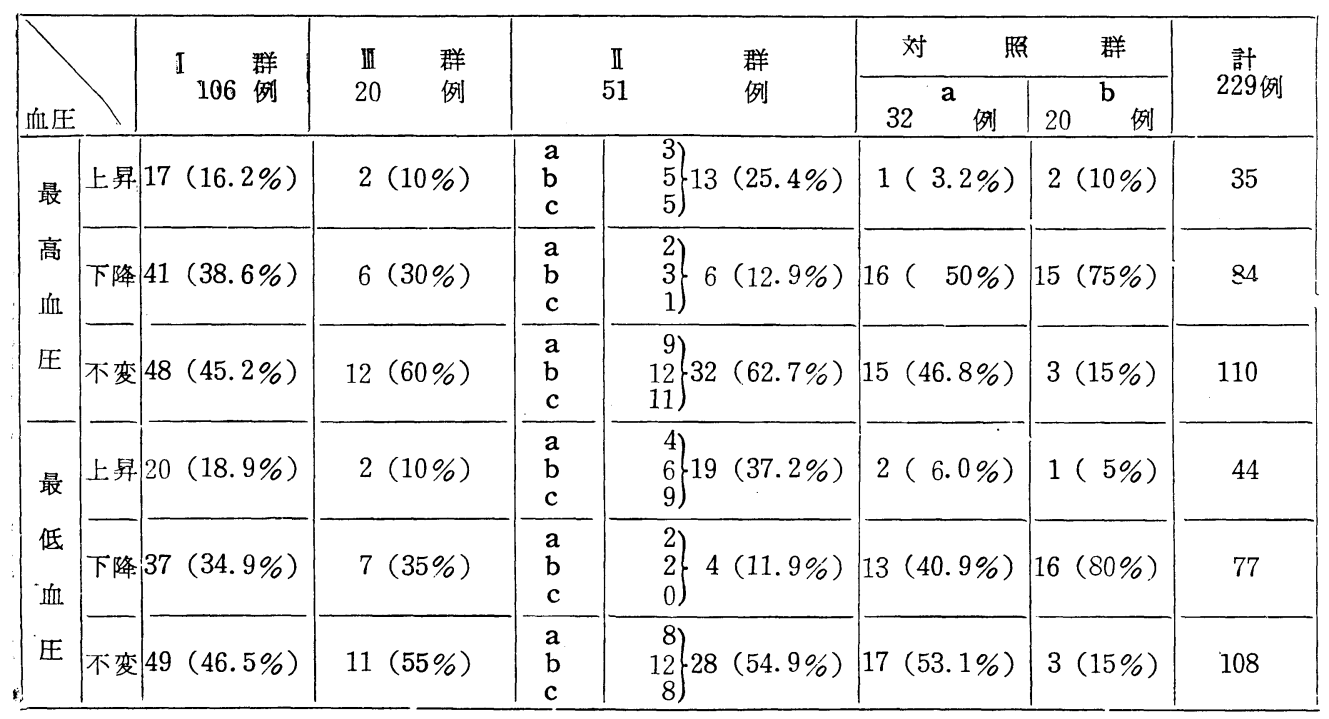


表16腎機能と血圧

\begin{tabular}{|c|c|c|c|c|c|c|c|}
\hline \multirow{3}{*}{\multicolumn{2}{|c|}{$\begin{array}{l}\text { 腎機能 } \\
\text { (治压 } \\
\text { 潦後) }\end{array}$}} & I C 排泄試験 & \multicolumn{2}{|c|}{ 水 試 験 } & $P \quad S \quad P$ & $\begin{array}{lll}\mathrm{N} & \mathrm{P} & \mathrm{N}\end{array}$ & \multirow{2}{*}{$\begin{array}{ll}\text { 尿 素 ク } \\
\text { 良 }\end{array}$} \\
\hline & & 不良 & 良 & 不良 & 不良 & 不良 & \\
\hline & & $(14.8 \%)(30 \%)$ & $(16.1 \%)$ & $\begin{array}{c}6 \\
(21.4 \%)\end{array}$ & $(17.6 \%)(19.1 \%)$ & $(20.6 \%)(35.2 \%)$ & $\begin{array}{c}7 \\
(30.4 \%)(28.6\end{array}$ \\
\hline 下 & 降 & $\begin{array}{cc}43 & 9 \\
(21.9 \%)(22.5 \%)\end{array}$ & $\begin{array}{c}18 \\
(26.6 \%)\end{array}$ & $\begin{array}{c}8 \\
(28.6 \%)\end{array}$ & $\begin{array}{cc}16 & 11 \\
(23.6 \%)(31.9 \%)\end{array}$ & $\begin{array}{cc}13 & 5 \\
(22.6 \%)(29.6 \%)\end{array}$ & $\begin{array}{cc}7 & 5 \\
(30.4 \%)(35.7 \%)\end{array}$ \\
\hline 不 & 変 & $\begin{array}{cc}72 & 19 \\
(53.3 \%) & (47.5 \%)\end{array}$ & $\begin{array}{c}39 \\
(57.3 \%)\end{array}$ & $\left.\begin{array}{c}14 \\
50 \%)\end{array}\right)$ & $\begin{array}{cc}40 & 18 \\
(58.8 \%)(50 \%)\end{array}$ & $\begin{array}{cc}33 & 6 \\
(56.8 \%)(35.2 \%)\end{array}$ & $\begin{array}{cc}9 & 5 \\
(39.2 \%) & (35.7\end{array}$ \\
\hline 計 & & 135 & 68 & 28 & 68 & 58 & 23 \\
\hline
\end{tabular}

のろちには PAS で副作用あり, 肝機能障害が認められ SM K代えて両機能とも好転をみたII 群 $\mathrm{c}$ の 1 例が含ま れるが，乙れも有意差を認めるに至らない。

偖，上記肝機能好転例中，腎機能の好転の及られなか つたものは 2 例のみであり, 又不変及び惡化群では全例 依然として腎機能障害がみられ，治療前肝障害の証明さ れない例で遠隔成績に於いて肝機能不全を示した場合, 腎機能障害も認められている。即ち，著者の観察でも， 両機能は略て並行して消長し, かつ, 治療後は腎機能改 善に遅れて, 肝機能好転を示す如き傾向が窺われた。

次に腎疾患と血圧とが密接な関係を有すととも周知の 所であり，池上 ${ }^{42)}$ は両側性腎結核，腎腫痬に於いてかな りの率汇高血圧症があり，尿管移植，腎摘出等によつて 比較的急速に正常化するものが多いととを報じ，江本 ${ }^{43}$ は各種泌尿器疾患に屡と認められる高血圧, 心筋障害は 腎性因子に基ずくものが多いと云う．著者の場合, RivaRocci 氏血圧計を用いて, 治療前・終了直後及び其後 1 カ月毎の測定を行なつた結果, 腎病変の程度 と血圧 と の間には必ずしも一定の関係はみられなかつたが, $11 \mathrm{~mm}$ Hg以上の增堿を以つて夫々血圧上昇及び下降とすると治 療後の血圧の変動は表15の如くになる．即ち，先ず全体 として, 最高血圧, 最低血圧とも, 治療後下降例が上昇 例に比して多くなつているが，変動を示したものと不変 と判定されたものとでは両者略く相半ばしている．但 し，対照 $\mathrm{b}$ 即与腎炎では不変例が僅か15\%に過ぎず，乙 れは明らかに他群のそれを下迴わつて打り，即ち㹂炎に 於いては治療により容易に血圧の変動するものが多いと とを暗示する成績である. 又各群間に於ける血圧変動の 状態をみるとI群・目群では下降例が上昇例より多いの に対し，II群では下降例が少くなつている. 即ち，腎摘 出術の行なわれた群では SM 療法のみの群に比し, 血 圧下降例が明らかに多く，腎結核の場合は昇圧因子があ る程度患腎自体に由来するもののように解される。一 方, 対照 $\mathrm{a}$ 即与非結核性泌尿器疾患で腎摘出群に於いて
も同様下降例が多くみられるが $\mathrm{b}$ の腎炎では，内科的療 法の及が行なわれたが矢張り上界例に比して下降例が多 くなつている．これらの関係は最高血圧及び最低血圧の。 何れについても指摘され，殊に後者に於いて著しい，な 打, 各群毎海高血圧平均值の治療前後の差をみると I 群では $5 \%$ の危険率, 対照aでは $\mathrm{I} \%$ 危険率で夫々有 意の血圧下降を, II 群 ๔では $1 \%$ \%危険率で有意の血圧 上昇が認められたが, II 群 $\mathbf{a}, \mathrm{b}$ ではその変動に有意差: を認め得なかつた(表略).. 次にこの血圧変動と腎機能と の関係は，表16に示す通りであり，一般に IC 排泄，水 試験, PSP, NPN 友び尿素ク等の 各機能不良群 は良好 群に比して, 治療後血圧上畕例の多い傾向にあるが, 有 意差の認められるのば IC 排泄能の良否に於いてのみで ある. 即ち, 血圧の変動と関係する腎性因子はむしろ, てれらの諸機能以外の要因に求める゙べものと推測され る. 更にこれらの血圧変動についての嗃隔成績をみると (表略), I 群ては治療終了直後最高血圧上昇 $16.2 \%$, 下 降 $38.6 \%$, 不変 $45.2 \%$, 最低血圧では上昇 $18.9 \%$, 下降 $34.9 \%$, 不変 $46.5 \%$ に対して, $1 \sim 2$ 年後に於ける遠隔: 成績の判明せる 32 例中最高血圧上昇 $34.3 \%$ ，下降 25.1 $\%$, 不変 $40.6 \%$, 最低血圧では土夫々 $31.3 \%, 21 \%, 46.9$ $\%$, II 群 a では直後最高血圧上界 $21.4 \%$, 下降 $14.3 \%$, 不变 $64.3 \%$, 最低血压上昇 $28.6 \%$ ，下降 $14.7 \%$ ，不変 57 $.1 \%$ に対して, 8 力月〜 2 年後に於ける 6 例では最高最 低血圧ともに上昇 $33.3 \%$ 。下降 $\cdot 0$, 不変 $66.7 \%$ で各群を 通じて治療終了後時を経るに従い血圧上昇例増加, 下降 例減少の傾向が看取される. しかし同 bでは, 直後最高 血圧上昇 $25 \%$, 下降 $15 \%$, 不変 $60 \%$, 最低血圧では夫々 $30 \%, 10 \%, 60 \%$ に対して，2〜5年後の12例に於ける 成績仙最高血圧上昇 $25 \%$, 下降 $8.3 \%$, 不変 $66.7 \%$, 最 低血圧上昇 $33.3 \%$,下降 $8.3 \%$ ，不変 $58.3 \%$ で直後と略 同様の状態を示している. 即与, 治療直後, 腎摘出術兼 化学療法群怡化学療法単独群比比し, 血圧下降例多く, 上昇例は少ないと云う結果を示したのに対し，遠隔成績: 
調查時に於いてはか〉る差異を認め難くなつているが, 治療直後に於ける上述の如き変動, 或いは化学療法単独 群と腎摘出群に於ける差異が一時的のものか否か等に関 しては, 残腎発病或いは再発の時期的問題並びに年令的 影響等を考慮に入れて今後の検索に俟たねばならない。

\section{結論}

腎結核に対する化学療法施行前後に於ける腎機能の消 長を IC 排泄試験・水試験（機能指数）・PSP 試験 血中 NPN 及び総腎尿素クについて観察して次の如き結 果を得た.

1）腎機能改善状態は腎摘出群（化学療法併用を含 む) と化学療法単独群とでは血中残余窒素以外は全て前 者が推計学的に有意差を以て後者に比して好い結果をも たらしている.

2） SM 使用量との関係では投与量を $15 \mathrm{~g} ， 16 \sim 30 \mathrm{~g}$, $31 \sim 60 \mathrm{~g}, 61 \mathrm{~g}$ 以上の 4 段階に分けた場合，（A）IC 排 泄試験では I 群, II 群 $\mathrm{a}$ 及び $\mathrm{b} て ゙ は$ 投与量 $30 \mathrm{~g}$ 程度の 好転率が最も高く, それ以上投与量が増加しても機能改 善が進まないように思われる. 然しII 群 $\mathrm{c}$ 即ち残腎結核 の場合では $\mathrm{SM}$ 量が60g 程度まで達したものの方が好 転率が高くなつている.（B）水試験・PSP - 残余窒素 ・尿素クも同様の傾向が認められるが一般に IC 排泄試 験に比べて機能改善に多くの SM 量を要するものの如 くである.

3）尿素クを中心として，乙れと各種検査成績との相 互関係を SM 使用前後を通じてみると, 先ず水試験と はI群以外何れも有意の順相関があり, I 群でも治療後 は有意の相関を示した. PSP とはI群，II群aでは治療 前後とも相関は少なく, 残余窒素とは II 群ては前後とも 有意の逆相関, I 群及び II 群でも治療後は有意の逆相関 が示された。

4）肝機能と腎機能は略 平行して消長し, かつ, 両 機能障害例では治療後腎機能改善に遅れて, 肝機能好転 を示す如き傾向が窅われた.

5）血圧との関係では腎摘出群（化学療法併用を含 む）は化学療法単独群に比し, 治療直後の血圧下降例多 く, 上昇例は少なかつたが, 各群を通じて治療後, 時を 経るに従い血圧上昇例增加, 下降例堿少の傾向を示し, 直後に於けるような差異は指摘し難い。

6）現段階では化学療法のみで腎結核の総ての症例を 治瘜せしめ得るものでないことを腎機能の面から再確認 した.

（要旨は第 48 回日本泌尿器科学会総会に於いて演述し
た).

\section{文献}

1）大塚，鈴木：日皮会誌，36，448,1935.

2) 北村 : 同誌, 35, 531, 1934 .

3）根岸：日泌尿会誌， $43 ， 189,1952$.

4) 富川：同誌, 44, 209, 1953.

5) 原：医学研究，23，1801，1953.

6）紊藤他：皮々泌， $20 ， 357,1958$.

7）金重：日泌尿会誌，48，6，443，1957.

8）百瀬他：同誌, 49, 7,655, 1958.

9) 西川：同誌, $50,9,938,1959$.

10) 堀内：同誌, $47,3,165,1956$.

11）荒川，近藤：弘前医誌， 6,23，32，1955.

12) 近藤 : 同誌, 8, 170, 1957.

13）荒川：同誌, 8,261, 1957.

14）齊藤他：皮々泌，21，5, 1959 .

15) 名和田他：同誌, 21, 532, 1959.

16）金井：臨床検査法提要, 金原出版, 東京, 1954.

17）吉川：臨床医化学 I 実驗編, 共同医書, 東京, 1955.

18）金子, 大島：日本臨床， $3,550,1954$.

19）金子：日新医学, 38, 233, 191, 290, 1951.

20）高田：日皮会誌, $40,1,1936$.

21）赤松：日泌尿会誌， $38 ， 29,1947$.

22) 藤原：岡山医誌, $64,75,1952$.

23）曾我部：同誌, 67, 289, 1955.

24）梄原：日泌尿会誌，46，28，1938.

25) 志賀: 泌尿器科学第 5 判, 日本医書出版, 東京, 1949.

26）岩倉：福岡医誌, 41, 102, 1950.

27）三輪：日医新報, $1730,94,1957$.

28) Glabstald: J. Urol., 66, 19, 1951.

29) Herman: J. Urol., 61, 122, 1949.

30）野見山：医学研究，23，1785，1948.

31) 大島 : 綜合医学, 13, 529, 1956.

32）大島：最新医学, 10,1788, 1955.

33) Nesbit, R.M. and Bohn, A.W.: J.A.M.A., 138, 937, 1948.

34) Lattimer, J.K. and Steans, W.H.: J. Urol., 60, 974, 1948.

35) Rinker, J.R.: J.A.M.A., 142, 87, 1950.

36) 土屋：日結, 9,64, 1950.

37) 稲田 : 同誌, 9, 133, 1950.

38）荒川, 松田：臨床の日本, 3, 558, 1957.

39）余藤他：皮と泌，19，5,1957.

40）大越：日泌尿会誌， $50,211,1959$.

41) 安原, 高木, 谷田：同誌, $43,197,1952$.

42）池上他：臨床と研究，34, 1015, 1957.

43）江本：皮と泌, 21, 114, 1959.

44) 山村：綜合臨床, 6,2253, 1957.

45）稲生他：同誌, 6,2327, 1957. 